\title{
TEMYIZ KANUN YOLUNDA UYGULANAN PARASAL SINIRIN HER YIL ARTIRILMASININ GÖRÜLMEKTE OLAN İDARİ DAVALARA ETKİİ
}

\author{
Doç. Dr. Yasin SÖYLER*
}

Muhammet YILMAZ $^{* *}$

Öz

İdari yargılama usulünde 2016 yılında getirilen yeni sistem, idari davaların esasen istinaf aşamasında bölge idare mahkemelerince kesin olarak çözümlenmesini öngörmektedir. Önemli olduğu varsayılan ve kanunda sınırlı olarak sayılan bazı davalar ise temyize tabi tutulabilmektedir. Temyize tabi tutulabilecek davalar kanunda sayılırken konu itibarıyla belirtilen bazı davaların yanı sıra, konusu para olan idari davalar açısından da bir belirleme yapılmıştır. Buna göre, yeni sistemin yürürlüğe konulduğu 2016 yılı itibarıla konusu yüz bin Türk Lirasını aşan vergi davaları, tam yargı davaları ve idari işlemler hakkında açılan davalar, temyize tabi tutulabilecek nitelikte olan davalardır. Fakat kanunda düzenleme altına alınan bu parasal sınırın, enflasyon karşısında değerini kaybetmemesi amacıyla her yıl yeniden değerleme oranına göre artırılmasına yönelik bir düzenlemeye de kanunda ayrıca yer verilmiştir. Bu noktada, bu şekilde her yıl artırılan temyiz sınırının görülmekte olan idari davaları da etkileyip etkileyemeyeceği konusu, önemli bir sorun olarak karşımıza çıkmaktadır. Makalede bu soruya bir cevap aranmaktadır.

* Doç. Dr., Ankara Sosyal Bilimler Üniversitesi Hukuk Fakültesi İdare Hukuku Anabilim Dalı, Ankara, Türkiye | Assoc. Prof., Social Sciences University of Ankara, Faculty of Law, Department of Administrative Law, Ankara, Turkey.

®yasin.soyler@asbu.edu.tr• ORCiD 0000-0002-8833-9230

** Danıştay Tetkik Hakimi, Ankara, Türkiye | Rapporteur Judge of the Turkish Council State, Ankara, Turkey.

囚muhammetyilmaz@hotmail.de • ORCID 0000-0002-5711-8478

Atıf Şekli | Cite As: SÖYLER Yasin / YILMAZ Muhammet “Temyiz Kanun Yolunda Uygulanan Parasal Sınırın Her Yıl Artırılmasının Görülmekte Olan İdari Davalara Etkisi", SüHFD., C. 29, S. 3, 2021, s. 2131-2168.

İntihal | Plagiarism: Bu makale intihal programında taranmış ve en az iki hakem incelemesinden geçmiştir. I This article has been scanned via a plagiarism software and reviewed by at least two referees. 
Anahtar Kelimeler

Temyiz • Parasal Sınır • Kanun Yolu • Hukuk Devleti • Hukuki Güvenlik

\title{
THE EFFECT OF YEARLY INCREASING THE MONETARY LIMIT APPLIED IN LEGAL REMEDY ON THE PENDING ADMINISTRATIVE CASES
}

\begin{abstract}
The new system on administrative trial procedure, which came into effect in 2016, foresees to substantially resolve administrative actions by regional administrative courts at the level of appeallate. On the other hand, cases assumed to be vital and qualified in the law may also be subject to appeal. When enumerating the cases that can be subject to appeal, in addition to the cases specified in terms of their subjects, a determination has been made for administrative actions, whose subject is money. According to this, as of the date of entery into force of the new system in 2016, tax actions, full remedy actions and actions filed about the administrative procedures exceeding one hundred Turkish Liras may be appealed. However, to preclude the monetary erosion of this financial limit, a new regulation has been introduced in the law so as to increase it in accordance with the revaluation ratio. At this point, whether increasing each year the financial limits will have repercussions for admnistative actions emerges as a vital problem. This essay is an attempt to address this problem.
\end{abstract}

Key Words

Appeal • Financial Limitation • Legal Remedy• Rule of Law $\bullet$ Legal Security

\section{GİRIŞ}

Türk idari yargılama usulünde davaları hızlı bir şekilde sonuçlandırabilmek ve yüksek mahkemelerin iş yükünü azaltarak onları tam anlamıyla içtihat mahkemesine dönüştürebilmek amacıyla, konusu para olan davalardan miktarı göreceli olarak düşük olanların temyize tabi tutulmaması yönünde bir hukuk siyaseti izlenmektedir. İdari Yargılama Usul Kanunu'nda bu anlayışı yansıtan hükümlere açıkça yer verilmiştir. Söz konusu kanunda, konusu para olan idari davalardan miktarı belirli bir düzeyi aşmayanlar temyize tabi tutulmamış, bölge idare mahkemesi kararlarıyla bu davaların kesinleşmesi kabul edilmiştir.

Öte yandan İdari Yargılama Usulü Kanunu'nda temyiz kanun yolu için öngörülmüş bu parasal sınırın, enflasyon karşısında değer kay- 
betmemesi için Hazine ve Maliye Bakanlığg'nca her yıl yayımlanan yeniden değerleme oranına göre artırılması yönünde bir esas da benimsenmiştir. Bu düzenleme karşısında anılan kanunda öngörülen temyiz sınırı her yıl artırılmakta ve temyiz kanun yoluna başvuru tarihine göre bu sınırın uygulanması durumu söz konusu olmaktadır.

Fakat bununla birlikte uygulamada, her yıl artan temyiz sınırının görülmekte olan davaları da etkileyeceği kabul edilmekte, Danıştay içtihatları bu şekilde bir gelişim göstermektedir. Bir diğer deyişle açıldığı tarihte temyize tabi olan bir dava, temyiz sınırındaki artıştan dolayı temyize başvurulduğu tarihte bu kanun yoluna tabi olmaktan çıabilmektedir. Bu nedenle de kişiler davalarını açtıkları vakit, bu davanın ileride temyize tabi olup olamayacağını tam olarak kestirememektedirler.

Bu uygulamanın pozitif hukukta, yani İdari Yargılama Usul Kanunu'nda bir karşılığının bulunup bulunmadığı ve ayrıca hukuk devleti ilkesi ile eşitlik ilkesine uygun olup olmadığ gerçekten incelenmeye değer bir konudur. Makalemizde bu sorulara yanıt aranmaya çalışılmıştir.

\section{PARASAL SINIRA DAYALI İDARİ YARGILAMA USULÜ}

Her şeyden önce belirtmek gerekir ki Türk idari yargılama usulünde parasal sınırlar, konusu para olan davalar açısından kabul edilmiştir. Keza parasal sınıra dayalı yargılama usulü, dava açma hakkının kullanılmasına ilişkin bir sınırlandırma olarak değil, aksine idari davalar açıldıktan sonra bunların tek hâkim ya da kurul halinde görülmesi, duruşma yapılmasına gerek olup olmaması ve özellikle istinaf ve kanun yollarına başvuru hakkının bulunup bulunmamasında belirleyici bir ölçüt olarak uygulanmaktadır. Bu nedenle Türk idari yargılama usulünde, konusu para olan idari davaların dava miktarı ne olursa olsun, miktara dayalı bir sınırlandırmaya tabi olmaksızın kişilerin dava açma hakkı bulunmaktadır. İdari yargılama usul kanunlarında zorunlu idari başvurunun öngörüldüğü hallerde bile bu zorunluluk, uyuşmazlıkların parasal miktarının esas alınmasından kaynaklanmamakta, yine idari davaların çözümünde arabuluculuk gibi alternatif uyuşmazlık çözüm yöntemleri kabul edilmediğinden, uyuşmazlık miktarına göre bu tür yöntemle- 
re başvurulmasını zorunlu kılan kurallar bulunmamaktadır. Açılan davaların kaybedilmesi halinde vekâlet ücreti de dâhil olmak üzere yarg1lama giderlerinin davacı üzerinde birakılması ise bundan farklı olarak dava açma hakkının kullanılmasını doğrudan sınırlandıran bir husus değildir.

Aşağıda ayrıntılı olarak inceleneceği üzere idari yargılama usulünde kabul edilen parasal sınırlara göz atıldığında, bu parasal sınırların, dava miktarı göreceli olarak düşük olmasından dolayı daha az önem taşıdığı varsayılan davaların hızlı bir şekilde sonuçlandırılması ve mahkemelerin iş yükünün hafifletilmesi amaciyla getirildiği görülmektedir ${ }^{1}$. Miktarı düşük olan davaların tek hâkimle karara bağlanması ve bunlar için duruşma zorunluluğunun öngörülmemesi bu davaların hızlı bir şekilde sonuçlandırılmasını amaçlarken, istinaf ve temyize ilişkin parasal sınırların² öngörülmesi ise bununla birlikte ayrıca bölge idare mahkemeleri ile Danıştay'ın iş yükünün hafifletilmesi amacını taşımaktadır. Anayasa Mahkemesi, yargılama usulüne ilişkin bu tür parasal sınırların ölçülü ve demokratik toplum düzeninin gereklerine uygun olması kaydıyla Anayasa'ya aykırılık oluşturmadığına karar vermektedir³.

1 Medeni yargılama usulü açısından aynı yönde bkz. ÖZBAY, İbrahim, “6100 Sayılı Hukuk Muhakemeleri Kanununa Göre İstinaftan Sonraki Temyiz Sistemimizde Temyiz Edilebilen ve Edilemeyen Kararlar", IÜHFM, C. LXIX, S. 1-2, 2011, s. 424.

2 Bundan sonra "istinafa ilişkin parasal sınır" deyimi "istinaf sınırı", "temyize ilişkin parasal sınır" deyimi ise "temyiz sınırı" olarak ifade edilecektir.

3 Anayasa Mahkemesi'ne göre, “31. Hukuk yargılamasında, sonuçları dikkate alındı̆̆ında bazı dava türleri ve değerine göre bazı davalar için (ceza yargılamasında olduğu gibi) 'az önemli davalar' kriteri altında temyiz sını öngörülmesinin ve kanunda belirlenen sinırı, adalet duygusunu rencide edecek veya hukuk devleti kavramıla bă̆daşmayacak sonuçlara yol açacak boyutta bulunmaması durumunda anayasal hakları ihlal etmeyeceği açıktır (AYM, E. 2006/65, K. 2009/114, 23/7/2009). 32. Bu kapsamda gereksiz başvuruların önlenerek dava sayısının azaltılması ve böylece mahkemelerin gereksiz yere meşgul edilmeksizin uyuşmazlıkların makul sürede bitirebilmesi (bitirilebilmesi olacak) amacıyla bir kısım mahkeme kararına karşı temyiz yolunun kapalı tutulmasının anayasal hakları ihlal ettiği söylenemez." AYM, Abdurrahman Şanda Başvurusu, B. No. 2014/3907, 7.12.2016, \& 27. Aynı yönde bkz. AYM, Emine Halaç ve Diğerleri Başvurusu, B. No. 2017/38981, 15.9.2020, \& 32. AYM, E. 1985/23, K. 1986/2, 20.1.1986. AYM, E. 2001/232, K. 2001/89, 23.5.2001. AYM, E. 2020/21, K. 2020/53, 1.10.2020, \& 30-37. Bununla birlikte doktrinde, istinaf ve temyize ilişkin bu şekilde parasal sınırlar belirlenerek bazı davalar bakımından kişilere kanun yoluna başvuru yolunun kapatılmasının, hak arama özgürlügüne ve bu bağlamda mahkemeye erişim hakkına aykırılık oluşturacağını sa- 
vunan yazarlar da vardır. Bu çerçevede özellikle temyiz sınırına ilişkin bu yöndeki bir görüş için bkz. YILMAZ, Ejder, "Hukuk Davalarında Yasayollarına Başvuru Hakkı ve Bu Hakkın Sınırlandırılmasının Yerindeliği Sorunu", Türkiye Barolar Birliği Dergisi, S. 1, 1988, s. 149-151. İdari yargilama usulünde istinaf ve/veya temyiz sınırına ilişkin aynı yönde bkz. AYDINOĞLU, Zeynep Nihal, "İstinaf Kanun Yolunun İdari Yargılama Usulüne Başlıca Etkileri", Türkiye Adalet Akademisi Dergisi, Y1l 9, Sayı 34, Nisan 2018, s. 401-402. BOZ, Selman Sacit/TETIK, Ahmet Talha/BÖLÜKBAŞI, Mustafa Oğuzhan/NACAK, Mehmet, Türk İdari Yargılama Hukukunda Temyiz, 1. Baskı, Ed. BOZ, Selman Sacit, Adalet Yayınevi, Ankara, 2021, s. 45, dipnot no. 125. AKYILDIZ, Ali, “İstinafa İlksel Bakmak”, Danıştay ve İdari Yarg1 Günü 147. Yıl Sempozyumu, Ankara, Mayıs 2015, s. 24. Kanaatimizce ölçülü olmak kaydıyla hukuk sistemimizde, tam yargı davaları bakımından istinaf ve temyiz konusunda parasal bir sinır belirlenmesine engel oluşturan anayasal bir hüküm bulunmamaktadır. Genel olarak idari davalara ilişkin aynı yönde bkz. ÇAĞLAYAN, Ramazan, İdarî Yargılama Hukuku, 12. Baskı, Seçkin Kitabevi, Ankara, 2020, s. 762. SEVINÇ, Ekin, "İdari Yargılama Hukukunda Kanun Yoluna Başvuru Hakkının Anayasal Güvenceye Sahip Olması Bakımından Ele Alınması", Ankara Hacı Bayram Veli Üniversitesi Hukuk Fakültesi Dergisi, C. XXIV, S. 3, 2020, s. 437. Medeni yargılama usulü açısından aynı yönde bkz. ALANGOYA, Yavuz, "Kanun Yolunun Anayasal Temeli ve HUMK m. 427 Hükmü ile Kanun Yolu Kapatılmış Olan Kararlara Karşı Kanun Yoluna Müracaat İmkanı”, TBB 75. Yaş Günü İçin Prof. Dr. Baki Kuru Armağanı, Türkiye Barolar Birliği Yayınları No: 55, Ankara, 2004, s. 40. İptal davaları açısından ise bunlardan konusu para olanları, parasal sınıra dayalı bir değerlendirmeyle istinaf ya da temyize tabi tutup tutmamanın isabetli bir yaklaşım olduğu söylenemez. Konusu para olan iptal davaları arasında, dava konusu parasal miktara dayalı olarak miktarı yüksek olan davaları daha önemli, düşük olan davaları ise daha önemsiz addetmenin mantıki bir izahı yoktur. Benzer yönde bkz. AKYILDIZ, s. 30. Bu davalar arasında istinaf ya da temyize tabi olmak açısından bir ayırım yapılacaksa eğer, bu ayrım dava konusu parasal miktara göre değil bizatihi davanın konusuna göre yapılmalıdır. Zira konusu para olan iptal davalarında, hukuka aykırılığı mahkeme kararıyla tespit edilen idari bir işlem ya da sözleşmenin hukuk âleminden silinmesi, parasal miktar düzeyine bakılmaksızın bu tür davaların tamamı açısından önemlidir ve hukuk devleti ilkesinin bir gereğidir. Aynı yönde bkz. AYDINOĞLU, s. 402. Bu nedenle ölçülülük ilkesine uygun olması kaydıyla, daha önemsiz olduğu varsayılan bazı iptal davalarının istinaf ya da temyiz denetiminden muaf tutulması mümkün olabilmeli, parasal sınıra dayalı bir yaklaşımdan ise uzak durulmalıdır. Ayrıca ülkemizde özellikle, aşağıda ayrıca belirtileceği üzere idari yargılama usulünde temyiz sınırı 2021 yılında 192.000 TL miktarına ulaştığından, bu miktarı temyiz kanun yoluna başvuru açısından ölçülü olarak değerlendirmek de mümkün değildir. Örneğin ortalama bir devlet memurunun özlük haklarından kaynaklanan çoğu davanın ya da sıradan kabahat oluşturan çoğu idari ihlal karşısında uygulanan idari para cezasının, bu temyiz sınırı karşısında temyize tabi bir dava olması mümkün olamayacaktır. Bu durum, devlet memurları ile söz konusu idari para cezalarına muhatap kişilerin mahkemeye erişim hakları ile hükmün denetlenmesini talep haklarının sınırlandırılmasında ölçüsüz bir müdahale ortaya çıardığı gibi sosyal devlet ilkesi ile eşitlik ilkesinin uygulanması açısından da so- 
Ayrıca idari yargılama usulünde yer verilen bu parasal sınırların, genel itibarıyla kamu düzenine ilişkin olduğu da kabul edilmektedir". Aslında bu parasal sınırlar belirli bir ölçüde mahkemelerin görev alanlarıyla da ilgili olduğundan ve idari yargılama usulünde görev konusu kamu düzeninden kabul edildiğinden, bunun doğal bir sonucu olarak da parasal sınırların kamu düzenine ilişkin olduğu söylenebilir. Parasal sınırların kamu düzeninden kabul edilmesi; bu sınırların kanun yolu aşamaları da dâhil olmak üzere yargılamanın her aşamasında gözetilmesini ve tarafların bir itirazı olmasa bile mahkemelerce re'sen dikkate alınmasinı zorunlu kılar 5 .

\section{A. Temyiz Kanun Yolunda Uygulanan Parasal Sinır}

2014 yılında yürürlüğe konulan 6545 sayılı Türk Ceza Kanunu ile Bazı Kanunlarda Değişiklik Yapılmasına Dair Kanun'la ${ }^{6}$ idari yargılama usulünde önemli değişiklikler yapılmış, bu çerçevede istinaf kanun yolu ilk kez hukuk sistemimize dâhil edilmiş ve bunun bir sonucu olarak temyiz kanun yolu yeniden düzenleme altına alınmıştır7. Üç dereceli bir

runlara neden olmaktadır. Konunun sosyal devlet ilkesiyle ilişkisi ve istinaf sınırı hakkında benzer yöndeki bir görüş için bkz. SEVINÇ, s. 437, 440-441. BOZ/TETIK/BÖLÜKBAŞI/NACAK, s. 92. Medeni yargılama usulünde uygulanan istinaf ve temyiz sınırı hakkında aynı yönde bkz. PEKCANITEZ, Hakan, "Hukuk Muhakemeleri Kanunu'nun Erozyon Süreci", Türkiye Barolar Birliği Dergisi, 133, 2017, s. 245. Öte yandan doktrinde, İYUK'ta öngörülen temyiz sınırının düşük olduğu, bunun yükseltilmesi gerektiğini savunan yazarlar da vardır. Bu yönde bkz. TOKLU, Esat, “İdari Yargının İstinaf Deneyimi, Karşılaştığı Sorunlar ve Çözüm Önerileri”, Danıştay Başkanlığı 150. Yıl Danıştay ve İdari Yargı Günü Sempozyumu 2018, Danıştay Yayınları No. 99, Ankara, 2018, s. 144-145. Yukarıda belirtilen gerekçelerle bu tür görüşlerin isabetli olduğu söylenemez.

4 Bu yöndeki bir karar için bkz. D.3.D., 5.3.2019, E. 2019/808, K. 2019/1570.

5 İdari yargılama usulünde kamu düzeni kavramının bu anlamı için bkz. AKYILMAZ, Bahtiyar/SEZGINNER, Murat/KAYA, Cemil, Türk İdari Yargılama Hukuku, 4. Baskı, Savaş Yayınevi, Eylül 2020, s. 132. ÇAĞLAYAN, İdarî Yargılama Hukuku, s. 123.

6 RG: 28.6.2014, 29044.

7 Bölge idare mahkemelerinin istinaf sistemine uygun bir şekilde göreve başlayacakları tarihe ilişkin olarak ise 2576 sayılı Bölge İdare Mahkemeleri, İdare Mahkemeleri ve Vergi Mahkemelerinin Kuruluşu ve Görevleri Hakkında Kanun'un geçici 20. maddesine, "Adalet Bakanlığı, bu Kanunun yürürlü̆ğe girdiği tarihten itibaren üç ay içinde, Kanunun, bu Kanunla değişik 3 üncü maddesinde öngörülen bölge idare mahkemelerini kurar. Bölge idare mahkemelerinin kuruluşlar, yargı çevreleri ve tüm yurtta göreve başlayacakları tarih, Resmî Gazete'de ilan edilir. Mevcut bölge idare mahkemeleri, yeni kurulan bölge idare mahkemelerinin göreve başlayacaklarn tarihe kadar faaliyetlerine devam ederler." 
sistem olarak öngörülen yeni yapılanmada ${ }^{8}$ kural olarak, konusu beş bin Türk lirasını ${ }^{9}$ geçmeyen vergi davaları, tam yargı davaları ve idari işlemlere karşı açlan iptal davaları hariç olmak üzere idare ve vergi mahkemelerince verilen kararlara karşı bölge idare mahkemelerine istinaf başvurusunda bulunulabileceği ${ }^{10}$; bölge idare mahkemeleri tarafından bu çerçevede verilen kararların ise İYUK'un 46. maddesinde açıkça sayılan davalar hariç olmak üzere kesin nitelik taşıyacağı belirtilmiştir (md. 45/6). Bu düzenleme ile idare ve vergi mahkemelerince verilen kararların kural olarak istinaf aşamasında kesin nitelikte çözüme kavuşturulması, istisnai olarak ise daha önemli olduğu varsayılan ve tahdidi olarak sayılan bazı davaların istinaf incelemesinden sonra ayrıca temyiz denetimine tabi tutulması amaçlanmıştır ${ }^{11}$. Bu yaklaşımda, Danıştay'ın iş

şeklinde bir hüküm konulmuş; bu hükmün gereği olarak söz konusu mahkemelerin, 20 Temmuz 2016 yılında tüm yurtta göreve başlayacakları Adalet Bakanlığı tarafından Resmî Gazete'de yayımlanan bir karar ile duyurulmuştur. Bu karar için bkz. RG: 7.11.2015, 29525.

8 AVCI, Mustafa, "İdari Yargıda İstinaf", Türkiye Barolar Birliği Dergisi, (96), 2011, s. 180. DEMİRKOL, Selami, "İdari Yargılama Usulü Yenilenirken İstinaf Kanun Yolu Öngörüsü-Danıştay'ın İçtihat Mahkemesi Rolü'nün Güçlendirilmesi", 148. Yıl Danıştay ve İdarî Yarg1 Günü Sempozyumu, Ankara, Mayıs 2016, s. 116.

9 Hazine ve Maliye Bakanlığı'nca belirlenen yeniden değerleme oranına göre bu sınır, 2021 yılında 7.000 TL olarak uygulanmaktadır.

10 İstisnai olarak İYUK'un 20/A ve 20/B maddelerinde düzenlenen ivedi yargılama usulü ile merkezî ve ortak sınavlara ilişkin yargılama usulünde ise idare mahkemelerince verilen nihai kararlara karşı bölge idare mahkemelerinde istinaf yoluna değil doğrudan Danıştay'da temyiz kanun yoluna başvurulabileceği öngörülmüştür.

11 BOZ/TETIK/BÖLÜKBAŞI/NACAK, s. 48. AYDINOĞLU, s. 394-395. AKYILDIZ, s. 25. SANCAKDAR, Oğuz, "İdari Yargı İstinaf Sistemindeki Olası Sorunlar ve Çözüm Önerileri", Danıştay ve İdarî Yargı Günü 148. Yıl Sempozyumu, Ankara, Mayıs 2016, s. 41. Bu arada belirtmek gerekir ki İYUK'un 46. maddesinin birinci fikrasında "Danıştay dava dairelerinin nihai kararları ile bölge idare mahkemelerinin aşă̆ıda sayılan davalar hakkında verdikleri kararlar, başka kanunlarda aksine hüküm bulunsa dahi Danıştayda, kararın tebliğinden itibaren otuz gün içinde temyiz edilebilir: ..." şeklinde bir hükme yer verilmiş olduğundan, ilk derece mahkemesi olarak Danıştay tarafından verilen kararların tamamı, parasal bir sınır değerlendirmesi yapılmaksızın temyize tabi tutulabilecektir. Benzer yönde bir düzenleme HMK'nın 362. maddesinde yer almasına rağmen Yargıtay Hukuk Genel Kurulu, aksi yönde bir karar vererek, bölge adliye mahkemelerinin kararları açısından getirilmiş olan temyiz sınırının ilk derece mahkemesi olarak bakılan davalarda Yargitay kararları açısından da geçerli olacağına hükmetmiştir. Bu karar ve bu kararın eleştirisi için bkz. KONURALP, Orhan Emre, "Hâkimlerin ve Bilirkişilerin Hukukî Sorumluluğuna İlişkin Verilen 
yükünün hafifletilerek dosyaların bu mahkemede uzun yıllar beklemesinin önüne geçilmesi ve Danıştay'ın tam anlamıla bir içtihat mahkemesine dönüştürülmesine yönelik bir hedef de bulunmaktadır ${ }^{12}$. Nitekim 6545 sayılı Kanun'un genel gerekçesinde bu hususa yönelik bir açıklamaya da yer verilmiştir ${ }^{13}$.

IYYUK'un 46. maddesinde tahdidi olarak (numerus clauses) sayılan davalara bakıldığında ise bu davaların büyük kısmının konu itibarıyla belirlendiği, sadece bir durumda ise konusu para olan davalar bakımından parasal sınıra dayalı bir belirleme yapıldığı görülmektedir. Konu itibarıyla yapılan belirlemelerde, işlem ya da mevzuat türüne göre bir ayrım yapılmış ${ }^{14}$, parasal sınıra dayalı belirlemede ise vergi davaları,

Mahkeme Kararları İçin Uygulanacak Kanun Yoluna Başvuru Sınırı Üzerine Bir Hukuk Genel Kurulu Kararının Düşündürdükleri", Hacettepe HFD, 9 (2), 2019, s. 540-545. Tespit edebildiğimiz kadarıyla Danıştay'ın bu yönde bir kararı bulunmamaktadır. Öte yandan açık HMK hükümleri karşısında Yargıtay'ın bu kararında isabet bulunmadığ 1 rahatlıkla söylenebilir.

12 BOZ/TETIK/BÖLÜKBAŞI/NACAK, s. 90. AKYILDIZ, s. 16. YILDIRIM, Ramazan, “Türkiye' de İstinaf Uygulamasının İdari Yargıya Etkileri”, Danıştay ve İdari Yargı Günü 147. Yıl Sempozyumu, Ankara, Mayıs 2015, s. 35. ASLAN, Zehreddin ve diğerleri, Açıklamalı ve İçtihatlı İdari Yargılama Usulü Kanunu (Vergi Yargılaması Dahil), Ed. ASLAN, Zehreddin, 1. Baskı, Seçkin, Ankara, 2019, s. 376.

13 Bu açıklama şu şekildedir: "2577 sayılı Kanunun 46 ncı maddesinde yapılan değişiklikle, istinaf mahkemelerince karara bağlanacak konulardan hangisinin temyiz yolu ile Danıştay'a gideceği belirlenmekte olup, bu maddede tahdidi olarak sayllan bu konular dışındaki davalarin bölge idare mahkemelerinde istinaf incelemesi neticesinde kesinleşmesi öngörülmektedir. Böylece Danıştay'ın temyizen karara bağladığı iş yükünün yaklaşık yüzde seksen oranında azaltılarak Danıştay'ın içtihat mahkemesi rolünün güçlendirilmesi amaçlanmaktadır." Bkz. https://www2.tbmm.gov.tr/d24/1/1-0918.pdf, Erişim Tarihi: 7.1.2021.

14 Örneğin "düzenleyici işlemlere karşı açılan iptal davaları" ya da "belirli bir meslekten, kamu görevinden veya öğrencilik statüsünden çıkarılma sonucunu doğuran işlemlere karşı açılan iptal davaları" şeklinde yapılan belirlemeler işlem türüne dayılı iken "maden, taşocakları, orman, jeotermal kaynaklar ve doğal mineralli sular ile ilgili mevzuatın uygulanmasına ilişkin işlemlere karşı açılan davalar" ya da “6/6/1985 tarihli ve 3218 sayılı Serbest Bölgeler Kanununun uygulanmasından doğan davalar" şeklinde yapılan belirlemeler ise mevzuat türüne dayalıdır. Bu ayrımin sonucu olarak mezkûr maddede öngörülen işlemler ve mevzuat türlerinden kaynaklanan iptal ve tam yargı davalarının, parasal sınıra ilişkin bir değerlendirme yapılmaksızın doğrudan Danıştay' da temyiz edilebilecek davalar olduğunun kabulü gerekir. Bu yönde verilmiş yakın tarihli Danıştay kararları bulunmaktadır. Bkz. D8D, 6.11.2020, E. 2020/4791, K. 2020/4978. D13D, 1.4.2019, E. 2019/1087, K. 2019/996. Fakat aksi yönde daha eski tarihli Danıştay kararları da vardır. Örneğin bir kararında Danıştay, maden mevzuatının uygulanmasından kaynaklı 76.010,00 
tam yargı davaları ve idari işlemler hakkında açılacak iptal davaları açısından dava konusunun 100.000 TL'yi aşmasi ${ }^{15}$ bir kriter olarak ortaya konulmuştur. Bu durumda, parasal sınır kriteri uygulanmaksızın 46. maddede konu itibarıyla sayılan davalarla bunun dışında kalan ve konusu 100.000 Türk lirasını aşan vergi davaları, tam yargı davaları ve idari işlemler hakkında açılan iptal davaları, başka kanunlarda aksine hüküm bulunsa dahi ${ }^{16}$ Danıştay'da temyiz edilebilecektir.

TL miktarındaki paranın iadesi amacıyla açılan bir davada -IYYUK'un 46. maddesine göre maden mevzuatının uygulanmasına ilişkin işlemlere karşı açılan davalar temyiz edilebilir niteliktedir-, dava konusu miktarın temyiz sınırının altında kaldığı gerekçesiyle temyiz istemlerini incelenmeksizin reddetmiştir. Bkz. D.8.D., 24.12.2018, E. 2018/6768, K. 2018/8939. Maden mevzuatının uygulanması konusunda aynı yöndeki diğer bazı Danıştay kararları için bkz. D.8.D., 10.12.2018, E. 2018/6508, K. 2018/8137. D.8.D., 14.2.2019, E. 2017/5537, K. 2019/1058. D.8.D., 21.2.2019, E. 2017/5628, K. 2019/1235. D.8.D., 14.1.2019, E. 2019/89, K. 2019/20. D.8.D., 10.12.2018, E. 2018/6605, K. 2018/8135. Bu yöndeki kararlar kanaatimizce isabetli değildir. IYYUK'un 46. maddesinde işlem ya da mevzuat türü belirtilerek yer verilen davalar, bunların konusunun para olmasından bağımsız olarak temyize tabi tutulabilecek davalar olarak sayılmıştır. Bu görüşe, anılan Danıştay kararlarında karşı oy olarak yer verilmiş olduğunu da ayrıca belirtmemizde fayda var. Nitekim bu esastan hareketle Danıştay 8. Dairesi, aksi yöndeki içtihadını sonradan bu şekilde değiştirmiştir.

15 İdari yargılama usulü ile medeni yargılama usulünde kabul edilen temyiz sinırı birbirinden farklıdır. İdari yargılama usulündeki temyiz sınırı 100.000 TL iken medeni yargılama usulündeki temyiz sınırı 40.000 TL'dir. Yeniden değerleme oranlarına göre yapılan artışlarla bu sınırlar, 2021 yılında sırasıyla 192.000 TL ve 78.630 TL'ye çıkmıştır. Ayrıca idari yargılama usulünde temyiz sınırı, alacağın tamamının dava edilmiş olup olmadığından bağımsız olarak dava dilekçesindeki talep miktarına göre belirlenirken, medeni yargılama usulünde alacağın tamamı esas alınarak mahkemece reddedilen miktara göre belirlenmektedir. Bu farklılıklardan dolayı örneğin 100.000 TL tazminat istemli bir davanın sirf adli ya da idari yargı mercilerinde görülmesine göre, verilen bölge idare ya da bölge adliye mahkemesi kararlarının temyize tabi olması ya da olmaması durumu söz konusu olmaktadır. Kanaatimizce bu farklılığı haklı kılan hiçbir neden bulunmamaktadır. Hatta idari yargılama usulündeki temyiz sınırının medeni yargılama usulüne göre çok daha yüksek tutulmaS1 ve alacağın tamamının dava edilmediği hallerde alacak miktarının tamamına göre değil de dava dilekçesinde belirtilen miktara göre davanın temyize tabi tutulup tutulamayacağına karar verilmesi, idari davalarda kişiler karşısında idareye haksız bir üstünlük sağlamaktadır. Bu durumun, idari davaların görülmesinde eşitlik ilkesi ile adil yargılanma hakkına aykırılık oluşturduğu söylenebilir.

16 IYYUK'un 46. maddesinin birinci fıkrasının ilk cümlesinde yer alan "başka kanunlarda aksine hüküm bulunsa dahi" ibaresi, bu ibareyi de bünyesinde barındıran 46 . madde değişikliğinin yürürlüğe girdiği 2014 tarihinden önce diğer kanunlarda yer 
Öte yandan İYUK'da, konusu 100.000 TL'yi aşan davalar açısından bu miktarın değer kaybının önüne geçilmesi amacıyla her yıl yeniden değerleme oranları esas alınarak bir artış yapılacağı öngörülmüştür. Buna göre, bu Kanunda öngörülen parasal sinırlar; her takvim yılı başından geçerli olmak üzere önceki yılda uygulanan parasal sınırların, o yıl için 213 sayılı Vergi Usul Kanunu'nun mükerrer 298. maddesi hükümleri uyarınca Hazine ve Maliye Bakanlığı'nca her yıl tespit ve ilan edilen yeniden değerleme oranında artırılması suretiyle uygulanacak ve bu şekilde belirlenen sinırların 1.000 TL'yi aşmayan kısımları dikkate alınmayacaktır (Ek madde 1) ${ }^{17}$. Ek 1. maddede yer verilen bu hüküm, IYYUK'da yer alan tüm parasal sınırlara uygulanabilir nitelikte olduğundan, temyiz sınırı olan 100.000 TL'nin de her yıl yeniden değerleme oranına göre artırılması söz konusu olmaktadır. İstinaf sisteminin uygulanmaya başlandığı 2016 yılında 100.000 TL olarak belirlenmiş olan bu sınır, bu tarihten sonra uygulanan yeniden değerleme oranlarının sonucu olarak 2017 yılında 103.000 TL, 2018 yılında 117.000 TL, 2019 yılında

alan aksi yöndeki hükümler bakımından uygulanabilir niteliktedir. Bu tarihten sonra yürürlüğe konulan kanunlarla aksi yönde hükümlerin getirilmesi halinde, sonraki tarihli hükmün önceliği ilkesi gereğince elbette bu sonraki tarihli kanun hükmünün uygulanması söz konusu olacaktır.

17 IYUK'taki hükme benzer şekilde 6100 sayılı Hukuk Muhakemeleri Kanunu'nda yer alan parasal sınırların her yıl yeniden değerleme oranına göre artırılmasına yönelik bir uygulamanın, hukuki belirliliği ortadan kaldırdığı ve bu nedenle hukuk devleti ilkesine aykırılık oluşturduğunu düşünen yazarlar da vardır. Bu yönde bkz. PEKCANITEZ, Hakan, "Yargıtay Yönünden Hukuk Muhakemeleri Kanunu'nun Değerlendirilmesi", TBB Dergisi, 144, 2019, s. 417-418. PEKCANITEZ, Hakan/ATALAY, Oğuz/ÖZEKES, Muhammet, "Hukuk Muhakemeleri Kanunu'nda Değişiklik Yapılmasına Dair 7251 Sayılı Kanun Hakkında Değerlendirme", Türkiye Barolar Birliği Dergisi, 150, 2020, s. 256, dipnot no. 9. İdari yargılama usulü açısından aynı yönde bkz. BOZ/TETIK/BÖLÜKBAŞI/NACAK, s. 92. Kanaatimizce bu yöndeki bir uygulama, doğrudan hukuki belirsizlik oluşturmaz. Tam aksine kanunlarda öngörülen parasal sınırların enflasyon karşısında tabiri caizse eriyip gitmesini engeller. Öte yandan her yıl yeniden değerleme oranına göre oluşan parasal sınırların bir tebliğle Resmî Gazete' de yayımlanmaması ve yeni miktarların Cumhurbaşkanlığı tarafından yayımlanan Mevzuat Bilgi Sistemi'ne işlenmemesinin ise bir hukuki belirsizlik oluşturacağı söylenebilir. Benzer yönde bkz. TAŞPINAR AYVAZ, Sema, "İstinaftan Sonraki Temyiz İncelemesi ve Sonuçları", Türkiye Barolar Birliği Medenî Usûl ve İcra-İflâs Hukukçuları Toplantısı VI, Medenî Usûl Hukukunda Kanun Yolları ve Arabuluculuk Kanun Tasarısı, İzmir/Çeşme, 19-20 Ekim 2007, s. 164-165. ÖZBAY, s. 425-426. 
144.000 TL, 2020 yılında 176.000 TL olarak uygulanmış ${ }^{18}, 2021$ yılında ise 192.000 TL olarak uygulanmaya devam etmektedir.

Bu noktada karşımıza şu şekilde önemli bir sorun çıkmaktadır: İYUK'da temyiz sınırına ilişkin yer verilen bu miktarlarda her yıl yapılan değişiklikler, daha önce açılmış olan idari davaları etkileyecek midir? ${ }^{19}$ Somutlaştırmak adına bir örnek üzerinden sorunu ele alırsak, örneğin bir kişi hakkında verilmiş olan 110.000 TL miktarındaki idari para cezasına karşı 2016 yılında açılan bir davada verilen ret kararı üzerine yapılan istinaf başvurusunda, bölge idare mahkemesince de 2019 yılında ret kararı verildiğini varsaydığımızda, bölge idare mahkemesince verilen bu karara karşı temyiz başvurusunda bulunulabilecek midir? $\mathrm{Bu}$ durumda ya kişinin 110.000 TL miktarındaki idari para cezasına karşı dava açtığı 2016 yılı esas alınarak bu yılda temyiz sınırı 100.000 TL olduğu için, bölge idare mahkemesince verilen karar 2019 yılına ilişkin olsa bile bu karara karşı temyiz başvurusunda bulunulabileceği ya da bunun tam aksine bölge idare mahkemesinin kararı 2019 yılına ilişkin olduğundan, bu yılda geçerli olan 144.000 TL miktarındaki parasal sınır esas alınarak temyiz başvurusunda bulunulamayacağı ileri sürülebilecektir. Hemen belirtmek gerekir ki Danıştay içtihadı, istikrarlı bir şekilde ikinci görüşten yana olmuştur. Bir alt bölümde Danıştay'ın bu içtihadını, aynı konu hakkında geliştirilmiş benzer yöndeki Anayasa Mahkemesi ve Yargıtay içtihatlarıyla birlikte ele alarak, ondan sonraki bölümde Danıştay'ın bu içtihadının hukuk devleti ve eşitlik ilkeleri açısından oldukça sakıncalı sonuçlar doğurmaya müsait olduğunu ifade etmeye çalışacağı.

Makalemizin inceleme konusu temyiz sınırının her yıl yeniden değerleme oranına göre artırılmasının görülmekte olan idari davaları ne şekilde etkileyeceğine ilişkin olmakla birlikte, bu inceleme sonunda ulaşacağımız bazı yargıların, 2577 sayılı İdari Yargılama Usulü Kanunu

18 https://www.turmob.org.tr/arsiv/mbs/pratikBilgiler/vergi_davalarinda_parasal_ sinirlar_2020-C.pdf, Erişim Tarihi: 11.2.2021.

19 Aynı sorunun vergi davaları açısından tartışıldığı bir çalışma için bkz. BALCI, Mustafa, "Vergi Yargısında Parasal Tutar Olarak Kesin Kararlar ve Kanuni Hâkim Yönünden Bazı Sakıncalı Durumlar", https://vergialgi.net/vergi-yargisinda-parasaltutar-olarak-kesin-kararlar-ve-kanuni-hakim-yonunden-bazi-sakincali-duruml, s. 2, Erişim Tarihi: 9.4.2021. 
(IYYUK)'nda parasal sınıra yer verilen diğer bazı konularla da ilişkili olabileceğini düşündügüumüzden, bütünleşik ve mukayeseye dayalı bir yaklaşım ortaya koyabilmek adına bu konulara da bu başlık altında ayrıca yer vermekte fayda görüyoruz.

\section{B. İstinaf Kanun Yoluna Tabi Davaların Belirlenmesinde Parasal Sinır}

IYYUK'un 45. maddesinin birinci fikrasına göre, “İdare ve vergi mahkemelerinin kararlarına karşı, başka kanunlarda farklı bir kanun yolu öngörülmüş olsa dahi, mahkemenin bulunduğu yargı çevresindeki bölge idare mahkemesine, kararın tebliğinden itibaren otuz gün içinde istinaf yoluna başvurulabilir. Ancak, konusu beş bin Türk lirasını geçmeyen vergi davaları, tam yargı davaları ve idari işlemlere karşı açılan iptal davaları hakkında idare ve vergi mahkemelerince verilen kararlar kesin olup, bunlara karşı istinaf yoluna başvurulamaz." Görüldüğü üzere konusu para olan idari davalarda istinaf kanun yoluna başvurulabilmesi için dava konusunun beş bin Türk Lirasını aşması gerekir. Kanunda öngörülen bu sınır, her yıl yeniden değerleme oranına göre artırıldığından en son 2021 yılında 7.000 TL miktarına gelmiştir. Konusu para olmayan davalarda ise haliyle bu sınır geçerli olmayacaktır. Bu nedenle bu nitelikteki davaların tamamı, istinaf kanun yolu denetimine tabi tutulabilir.

Yukarıda belirtildiği üzere aynen temyiz sınırının belirlenmesinde olduğu gibi istinaf sınırının belirlenmesinde de davanın açıldığı tarihte mi yoksa ilk derece mahkemesinin karar verdiği tarihte mi geçerli olan parasal sınırın esas alınacağına ilişkin İYUK'ta açık bir hüküm bulunmamaktadır. Hazine ve Maliye Bakanlığı'nca yayımlanan yeniden değerleme oranlarına göre istinaf sınırı her yıl artırıldığından, doğrudan uygulama ilkesi gereğince bölge idare mahkemeleri, ilk derece mahkemelerinin karar verdiği tarihte geçerli olan istinaf sınırını esas almaktadır$\operatorname{lar}^{20}$. Bölge idare mahkemelerinin bu yaklaşımı, aşağıda ayrıntılı bir şe-

20 İstanbul Bölge İdare Mahkemesi 6. İdari Dava Dairesi, 25.1.2021, E. 2020/1015, K. 2021/198. Ankara Bölge İdare Mahkemesi 6. İdari Dava Dairesi, 3.2.2021, E. 2020/1241, K. 2021/274. Gaziantep Bölge İdare Mahkemesi Birinci İdari Dava Dairesi, 30.11.2020, E. 2020/1405, K. 2020/594. Bu son kararın künyesine BALCI'nın makalesinden ulaşılmıştır. Bkz. BALCI, s. 8. Bölge idare mahkemelerinin bu çerçevede vermiş olduğu kararlara karşı yapılan temyiz başvurularında Danıştay da bölge 
kilde inceleneceği üzere temyiz sınırı ile ilgili Danıştay yaklaşımı ile aynı yöndedir. Fakat parasal olarak, temyiz kanun yoluna göre istinaf sinır1nın hem düşük olması hem de bundan kaynaklı olarak yeniden değerleme oranlarına göre bu sınırda yapılan değişikliklerin her yıl yüksek miktarlarda artmamasından dolayı, burada ele almaya çalıştığımız sorunun bölge idare mahkemesi kararlarına yansıyan çok fazla bir yönü bulunmamaktadır. Buna rağmen biz temyiz sınırında yapılan artışların görülmekte olan idari davaları etkilememesi gerektiğine ilişkin görüşümüzün, üçüncü bölümde belirtilen aynı gerekçelerle istinaf sınırındaki artışlar bakımından da geçerli olması gerektiği kanaatindeyiz.

\section{Tek Hâkimle Bakılabilecek Davaların Belirlenmesinde Parasal Sinir}

İlk derecede Danıştay'da görülecek davalar bir tarafa bırakılırsa kural olarak idari davalar, idare ve vergi mahkemelerinde açılır. Bölge idare mahkemeleriyle birlikte idare ve vergi mahkemelerinin kuruluş ve görevlerini düzenleyen 2576 sayılı Bölge İdare Mahkemeleri, İdare Mahkemeleri ve Vergi Mahkemelerinin Kuruluşu ve Görevleri Hakkında Kanun'a göre ise idare ve vergi mahkemelerinde birer başkan ile yeteri kadar üye bulunur ve mahkeme kurulları başkan ile iki üyeden oluşur (md. 4). Fakat istisnai olarak idare ve vergi mahkemelerinde açılan bazı davalar, kurul halinde değil tek hâkimle çözümlenebilmektedir. Bu husus hakkında anılan Kanunun 7. maddesinde özel bir hükme yer verilmiştir. Buna göre,

“1. Uyuşmazlık miktarı yirmibeşbin Türk Lirasını aşmayan;

a) Konusu belli parayı içeren idarî işlemlere karşı açılan iptal davaları,

b) Tam yargz davaları,

İdare mahkemesi hâkimlerinden biri tarafından çz̈zümlenir.

2. 6 nol maddenin (a) ve (b) bentlerinde belirtilen uyuşmazliklardan kaynaklanan toplam değeri yirmibeşbin Türk Lirasını aşmayan davalar, vergi mahkemesi hâkimlerinden biri tarafindan çözümlenir." Görüldüğü üzere bu hükümle, konusu para olan idari davaların idare ve vergi mahkemelerinde 
görülmesinde, uyuşmazlık miktarının belli bir düzeyi aşmasına göre davaların tek hâkimle veya kurul halinde görülmesine ilişkin bir esas benimsenmiştir. Aynı Kanunun ek 1. maddesinde, burada öngörülen 25.000 TL miktarındaki parasal sınırın değer kaybına uğramaması amacıyla, her takvim yılı başından geçerli olmak üzere Hazine ve Maliye Bakanlığı'nca belirlenen yeniden değerleme oranına göre artırılacağ 1 da belirtilmiştir ${ }^{21}$. Bu çerçevede ilan edilen yeniden değerleme oranlarına göre burada yer verilen 25.000 TL miktarındaki parasal sınır, 2021 yılı için 57.000 TL olarak uygulanmaktadır²2.

Öte yandan 2576 sayılı Kanun'un ek 1. maddesinde, makalemizde ulaşacağımız sonuçlar açısından oldukça önem taşıyan konu ile ilgili bir hükme daha yer verilmiştir. Ek 1. maddenin ikinci fikrasına göre, "Yukarıdaki fikra uyarınca her takvim yılı başından geçerli olmak üzere uygulanan parasal sınırların artışı, artışın yürürlüğge girdiği tarihten önce idare ve vergi mahkemelerince nihâ̂ olarak karara bağlanmış davalar ile Danıştayın bozma

212576 sayılı Kanun' da yer verilen bu hükmün aynısına istinaf ve temyiz sınırları ile duruşma sınırı bakımından İYUK'un ek 1. maddesinde de yer verilmiştir. Bu çerçevede söz konusu kanunlarda yer alan parasal sınırlar, Hazine ve Maliye Bakanlığ1 tarafından her yıl bir tebliğle Resmî Gazete'de yayımlanan yeniden değerleme oranına göre artmakta ve fakat yeniden değerleme oranındaki artışların, bu kanunlarda yer alan parasal sınırları hangi miktara getirdiğine ilişkin bir hesaplama yapılarak yeni yılda uygulanacak parasal sınırlar ayrıca ilan edilmemektedir. Hâlbuki diğer bazı kanunlarda yer alan parasal sınırlar açısından bu sınırların yeniden değerleme oranlarına göre hangi miktara kadar yükseldiği, her takvim yılı öncesinde yürürlüğe konulan tebliğlerle ilan edilmektedir. Örneğin 6502 sayılı Tüketicinin Korunması Hakkında Kanun'un 68. maddesinde, belirli bir miktarın altında bulunan uyuşmazlıklara karşı hakem heyetlerine başvuru zorunluluğuna ilişkin hükümler getirilmiş, bunların her yıl yeniden değerleme oranlarına göre artırılması hüküm altına alınmış ve bu çerçevede her takvim yılı öncesinde yeniden değerleme oranlarına göre söz konusu kanunda yer alan bu parasal sınırların hangi miktara gelmiş olduğu belirlenerek Resmî Gazete'de bir tebliğle yayımlanmıştır. Bu çerçevede söz konusu parasal sınırların 2021 yılında hangi miktara gelmiş olduğunu ilan eden tebliğ için bkz. 6502 Sayıl Tüketicinin Korunması Hakkında Kanunun 68 inci ve Tüketici Hakem Heyetleri Yönetmeliğinin 6 ncı Maddelerinde Yer Alan Parasal Stnırları Artırılmasına İlişkin Tebliğ, RG: 26.12.2020, 31346. Kanaatimizce hukuki belirlilik ilkesi gereğince, aynı yöntemin idari yargılama usulünde kabul edilmiş olan parasal sınır artışları açısından da uygulanmasına yönelik bir zorunluluk getirilmelidir.

$22 \quad$ 28.11.2020 tarihli ve 31318 sayılı Resmî Gazete'de yayımlanan Vergi Usul Kanunu Genel Tebliği (Sıra No: 521) ile yeniden değerleme oranı 2020 yılı için \% 9,11 olarak tespit edilmiştir. 
kararı üzerine bozulan mahkemece yeniden bakılan davalarda uygulanmaz." Bu hükmün mefhum-u muhalifinden anlaşılmaktadır ki idari davaların tek hâkimle çözümlenmesine ilişkin parasal sınırdaki artışlar, görülmekte olan idari davaları etkileyecek ve yeni yılda yürürlüğe konulan artırılmış parasal sınırlara göre, davaların yeniden tek hâkimle mi yoksa kurul halinde mi bakılması gerektiğine karar verilmesi gerekecektir ${ }^{23}$. Fakat artışın yürürlüğe girdiği tarihten önce idare ve vergi mahkemelerince nihai olarak karara bağlanmış davalar ile Danıştay'ın bozma kararı üzerine yeniden bakılan davalarda bu hüküm uygulanmayacaktır ${ }^{24}$. Bizi ilgilendiren boyutuyla konuyu bir örnek üzerinden somutlaştırmak gerekirse tek hâkimle çözülecek davalarda parasal sınırın 44.000 TL olduğu 2019 yilında 50.000 TL tazminat istemiyle açlan bir dava ${ }^{25}, 2019$ y1lı içerisinde idare mahkemesinde kurul halinde görülecek ve fakat bu davada 2021 yılında karar verilmesi durumu söz konusu olduğunda bu yıldaki parasal sınır 55.000 TL olduğundan, dolayısıyla 50.000 TL tazminat istemini içeren dava bu yıl için geçerli olan parasal sınırın altında kaldığından bu davanın tek hâkimle sonuçlandırılması gerekecektir ${ }^{26}$.

23 “Olayda, iptali istenilen daval idare işleminin konusu(nu) oluşturan hacizlerin dayană̆ı kamu alacağının miktarının karar tarihi itibarıla anılan kanunda tek hâkimle çözümlenecek davalar için öngörülen 36.000,00 TL stnırının üstünde olması nedeniyle davanın mahkeme kurulunca karara bağlanması gerekirken, tek hâkim tarafından görülüp çözümlenmesi yargılama hukukuna uygun düşmemiştir." D.3.D., 5.3.2019, E. 2019/808, K. 2019/1570. (Alt çizgi, konunun vurgulanması amacıyla tarafımızca konulmuştur.)

24 Bu yönde bkz. İstanbul Bölge İdare Mahkemesi 1. Vergi Dava Dairesi, 27.10.2016, E. 2016/943, K. 2016/126. Konya Bölge İdare Mahkemesi 5. İdari Dava Dairesi, 23.3.2017, E. 2017/270, K. 2017/292.

25 Medeni yargılama usulünden farklı olarak idari yargılama usulünde istinaf ve temyiz sınırları, dava dilekçesinde gösterilen miktara göre ya da iptal davalarında idari işlemin para olan konusuna göre belirlenmektedir. Bkz. CANDAN, Turgut, Açılamalı İdari Yargılama Usulü Kanunu, 8. Baskı, Yetkin Yayınları, Ankara, 2020, s. 1087. Bu uygulama Danıştay içtihatlarıyla gelişmiştir.

26 Bölge idare mahkemeleri, tek hâkimle verilecek kararlarda parasal sınırı genellikle ilk derece mahkemelerince karar verildiği tarihe göre belirlemektedir. Örnek bir karar için bkz. "... konusu belirli bir miktar paraya ilişkin olan işlemlerin iptali istemiyle açlan 'iptal davaları' ile bu nitelikteki işlemler üzerine birlikte açılan 'iptal ve tam yargı davaları'nda, Mahkemenin (ilk derece mahkemesi kastediliyor) karar verdiği tarih itibarıla 2576 sayıl Kanun'un Ek 1. maddesinde belirtilen değerleme oranına göre, o yıl için belirlenen parasal sınırın altında kalan uyuşmazlıkların tek hâkim tarafindan çözümlenmesi gerekmektedir." Gaziantep Bölge İdare Mahkemesi 3. İdari Dava Dairesi, 25.1.2018, E. 2017/2119, K. 2018/146. Fakat aksi yönde, tek hâkimle verilecek kararlarda parasal 
$\mathrm{Bu}$ düzenlemenin neden olabileceği mağduriyetleri ve hak ihlallerini şimdilik bir tarafa bırakarak, konumuz açısından önem taşıması nedeniyle burada tek hâkimle çözülecek davalarda parasal sınıra ilişkin artışların görülmekte olan idari davalara etkisi hakkında açık bir düzenlemeye yer verilmiş olduğu hususuna işaret etmemiz gerekir. Aşağıda ayrıntılı olarak inceleneceği üzere temyiz sınırını düzenleyen IYYUK'ta, her yıl gerçekleşen artışların görülmekte olan idari davaları bu şekilde etkileyeceğine ilişkin açı bir düzenlemeye yer verilmemiştir. İYUK'ta bu şekilde açık bir düzenlemeye yer verilmemiş olmasının bir anlamı bulunmadığı, buna rağmen her yıl artırılan temyiz sınırının görülmekte olan idari davaları yine de derhal uygulama ilkesinin gereği olarak etkileyeceği savunulabilirse de -ki biz bu düşüncede olmadığımızı aşağıda ayrıntılı bir şekilde izah etmeye çalışacağız- 2576 sayılı Kanun'da açıkça yer alan söz konusu hükümden hareketle geliştirilen bir uygulamanın, temyiz sınırı konusuna teşmil ettirilemeyeceği de şüphesizdir.

\section{Duruşmalı İşlerde Parasal Sınır}

İYUK'un 17 ilâ 19. maddelerinde, idari davaların görülmesinde duruşma usulü düzenlenmiş ve burada da bazı davaların duruşmalı görülebilmesi açısından parasal sınırlar öngörülmüştür. Fakat IYUK'ta yer alan parasal sınıra ilişkin diğer düzenlemelerden farklı olarak 17. maddede, iptal davalarının görülmesinde taraflardan birinin isteği üzerine duruşma yapılma zorunluluğuna ilişkin bir düzenlemeye yer verilmiştir. Yani iptal davasının konusunu paranın oluşturup oluşturmaması önem arz etmeksizin, bu davalarda taraflardan birinin isteği varsa

sınırı davanın açıldığı tarihe göre belirleyen bölge idare mahkemesi kararları da vardır. Örnek bir karar için bkz. Konya Bölge İdare Mahkemesi 1. Vergi Dava Dairesi, 16.1.2020, E. 2019/609, K. 2020/53. Bu yöndeki kararlar aşağıda görüleceği üzere aslında bizim savunduğumuz ilkelere daha uygun olmakla birlikte, 2576 sayılı Kanun'un ek 1. maddesinin ikinci fikrasında yer alan "Yukarıdaki fikra uyarınca her takvim yılı başından geçerli olmak üzere uygulanan parasal sınırların artışı, artışın yürürlüğe girdiği tarihten önce idare ve vergi mahkemelerince nihâ̂ olarak karara bağlanmış davalar ile Danıştayın bozma kararı üzerine bozulan mahkemece yeniden bakılan davalarda uygulanmaz." hükmüne uygun değildir. Bu hükmün mefhum-u muhalifinden çıkan sonuç, tek hâkimle verilecek kararlardaki parasal sınırın, davanın açıldığı tarih değil ilk derecede karara bağlandığı tarihe göre belirlenmesidir. Böyle bir hüküm IYYUK'ta yer almadığı için, burada söylenenlerin elbette istinaf ve temyiz sınırı hakkında da uygulanması gibi bir sonuç ortaya çıkmayacaktır. 
idari mahkemeler duruşma yapmak zorundadırlar ${ }^{27}$. Aynı hükümde, tam yargı davalarının görülmesinde -madde hükmü vergi davalarını da kapsamına alacak bir içerik taşımaktadır- duruşma usulüne başvurulabilmesinin ise dava konusunun 25.000 TL'yi aşması gerektiğine ilişkin bir hükme yer verilmiştir. Yeniden değerleme oranına göre bu sınır 2021 yılında 57.000 TL miktarına ulaşmıştır. Şu halde idari mahkemelerde açılan ve konusu para olan tam yargı davalarında duruşma yapılabilmesi için talep edilen tazminat miktarının 2021 yılı için 57.000 TL'yi aşması gerekecektir. Aksi durumda taraflar bir talepte bulunsa bile duruşma yapılması mümkün olmayabilecektir ${ }^{28}$.

Fakat burada da duruşma yapılmasına ilişkin parasal sınırın hangi tarih esas alınarak belirleneceğine ilişkin açı bir hükme İYUK'ta yer verilmemiştir. Duruşma talebinin yerine getirilmesi açısından dava tarihinde geçerli olan parasal sınır mı, yoksa duruşmanın yapılacağı tarihteki parasal sınır mı esas alınacaktır? Danıştay'ın temyiz sınırı hakkında dava tarihinin değil de bölge idare mahkemesince karar verildiği tarihin esas alınacağı yönündeki içtihadını esas alırsak, burada da duruşmanın yapılacağ verilmesi gerektiği sonucuna varılacaktır. Yani kişinin açmış olduğu tam yarg1 davasında, dava tarihi itibarıyla tazminat talebinin duruşma sınırının üstünde olması halinde bu davanın; duruşmalı bir şekilde görülebilmesi mümkün iken, ilerleyen süreçte duruşma sınırının yeniden değerleme oranına göre artması karşısında duruşma talep edilemeyecek bir davaya dönüşmesi söz konusu olabilecektir. Kanaatimizce böyle bir uygulama üçüncü bölümde belirtilen gerekçelerle hukuki güvenlik ilkesine aykırılık oluşturduğu gibi, açılmış bir tam yargı davasının bir dönem duruşma yapılabilen, bir dönem ise duruşma yapmaya müsait olmayan bir dava halini alması nedeniyle garip bir sonuç da ortaya çıkaracaktır.

27 Fakat IYYUK'un 17. maddesinin ikinci fikrasına göre, “Temyiz ve istinaflarda duruşma yapılması tarafların istemine ve Danıştay veya ilgili bölge idare mahkemesi kararına bağlldır."

28 IYYUK'un 17. maddesinin dördüncü fıkrasına göre, idari davalarda Danıştay, mahkeme veya hâkim tarafların talebi olmasa da re'sen duruşma yapabilme yetkisine sahiptir. Bu nedenle iptal ve tam yargı davalarında dava konusu miktar önem arz etmeksizin, mahkeme kendiliğinden duruşma yapma kararı alabilir. 


\section{TEMYIZ SINIRININ HER YIL ARTIRILMASININ} GÖRÜLMEKTE OLAN DAVALARA ETKISIINE İLIŞKİN MAHKEME İÇTİHATLARI

Temyiz sinırının her yıl artırılmasının görülmekte olan davalara etkisi hakkında Anayasa Mahkemesi, Danıştay ve Yargıtay'ın aynı yönde ve fakat farklı gerekçelere dayandırarak geliştirmiş olduğu içtihatlar vardır. Bu başlık altında söz konusu içtihatları tespit ederek bunların, usul kanunlarında yer alan düzenlemelere ne derece uygunluk gösterdiğini tartışacağız. Burada tespit edeceğimiz Danıştay içtihadının, hukuk devleti ve eşitlik ilkelerine uygunluğunu ise üçüncü bölümde ayrı bir başlık altında inceleyeceğiz.

\section{A. Danıştay İçtihadı}

İYUK'a göre, temyiz başvurusunun kesin bir karar hakkında olması halinde kararı veren merciin temyiz isteminin reddine karar vermesi gerekir (md. 48/6). Buna göre bölge idare mahkemesince verilen bir kararın temyiz edilmiş olması halinde, bu mahkeme temyiz başvurusunun kesin bir karar hakkında olup olmadığını inceleyecek ve başvurunun kesin bir karar hakkında olduğuna kanaat getirdiği takdirde istemi reddedecektir. Aynı fıkrada, ilgili merciin bu kararlarına karşı, tebliğ tarihini izleyen günden itibaren 7 gün içinde temyiz yoluna başvurulabileceği de belirtildiğinden bölge idare mahkemelerinin temyiz sinırı gerekçesiyle vermiş oldukları temyiz isteminin reddi kararlarına karşı Danıştay'a temyiz başvurusu yapılabilmektedir ${ }^{29}$. Öte yandan Danıştay, İYUK'un 48. maddesinin yedinci fıkrası çerçevesinde, bölge idare mahkemelerince temyiz yolu açık olmak üzere verilen kararların temyiz

29 Bu kapsamda yapılmış bir temyiz başvurusu üzerine Danıştay 8. Dairesi'nce verilen bir karara ilişkin bkz. D.8.D., 30.6.2020, E. 2020/3346, K. 2020/2917. Öte yandan bölge idare mahkemelerinin kesin nitelikte vermiş oldukları kararlara karşı yine bu mahkemeler nezdinde "itirazen düzeltme" başvurusunda bulunulamaz. İYUK'ta böyle bir kanun yolu öngörülmemiştir. İYUK'un 30. maddesinde yer verilmiş olunan "yanlışlıkların düzeltilmesi" hükmü de bu tür başvurular hakkında karar verilmesine imkân tanıyan bir düzenleme olarak değerlendirilemez. Buna rağmen bölge idare mahkemeleri bazen bu şekilde yapılan başvuruları incelemekte ve fakat burada belirtmiş olduğumuz gerekçeyi göz ardı ederek karar verebilmektedirler. $\mathrm{Bu}$ yönde verilmiş bir karar için bkz. Ankara Bölge İdare Mahkemesi 4. Vergi Dava Dairesi, 10.7.2019. E. 2019/1264, K. 2019/1302. 
edilmesi üzerine, aslında bu kararların temyize tabi tutulamayacak kararlar olduğundan bahisle de temyiz başvurularını incelenmeksizin reddedebilmektedir. Zira söz konusu hükme göre, temyiz başvurusunun kesin bir karar hakkında olduğunun temyiz aşamasında anlaşılması halinde, ilgili Danıştay dairesinin temyiz isteminin reddine kesin olarak karar vermesi gerekir. Danıştay bu çerçevede konuya ilişkin kararlarında genellikle örneğin, “2577 sayıl Kanunun 46. maddesi uyarnca temyize tabi olmayan söz konusu karar hakkında, İzmir Bölge İdare Mahkemesi 4. İdari Dava Dairesince temyiz yolu açık olmak üzere karar verilmiş olmasının, 2577 sayılı Kanunun 46. maddesi uyarnca temyiz yolu öngörülmeyen karara, kanun yolu ile öngörülmeyen temyiz kanun yolu incelemesi yapılması hakkı kazandırmayacă̆ı da açıktır." şeklinde açıklamalara da yer verme gereği hissetmektedir ${ }^{30}$. Bu çerçevede her ne şekilde olursa olsun nihayetinde idari yargılama usulünde temyiz sınırının belirlenmesi, büyük ölçüde Danıştay içtihatlarıyla şekillenmektedir.

Danıştay, temyiz sınırının belirlenmesinde istikrarlı bir şekilde bölge idare mahkemesi karar tarihinin esas alınması gerektiği yönünde kararlar vermektedir. Yani Danıştay'a göre, temyiz sınırının belirlenmesinde davanın açlmış olduğu tarih esas alınamaz; tam aksine bölge idare mahkemelerince karar verildiği tarih esas alınmalıdır. Örneğin Danıştay bir kararında, başkasına ait taşınmaz üzerinde ruhsatsız inşaat yapıldığından bahisle İmar Kanunu gereğince verilen 110.937 TL idari para cezasına karşı 2015 yılında iptal davası açılmış olmasına rağmen -2015 yılında söz konusu miktar temyiz sınırının üzerinde kalmaktadır-, istinaf incelemesinde bölge idare mahkemesince 2018 yılında karar verildiği ve bu yılda yeniden değerleme oranına göre temyiz sınırının 117.000 TL olduğu gerekçesiyle davacının temyiz istemini incelenmeksizin reddetmiştir ${ }^{31}$. Yine bir başka kararında Danıştay, 2017 yılında temyiz sınırı 103.000 TL olmasına rağmen, 120.000 TL miktarındaki idari para cezası-

30 Bu yönde bir örnek karar için bkz. D.14.D., 17.10.2018, E. 2018/4601, K. 2018/6204.

31 Bkz. “Anılan Kanun hükümlerinin değerlendirilmesinden, 46. maddede belirlenen temyize tabi uyuşmazlık miktarının her yıl yeniden değerleme oranında artırılacağı, davaya konu uyuşmazlık miktarının istinaf mahkemelerince kararın verildiği tarihte geçerli olan, 46. maddede belirlenen temyize tabi miktarın üzerinde olması halinde kararın temyiz edilebileceği anlaşılmaktadır." D.14.D., 17.10.208, E. 2018/4601, K. 2018/6204. 
na ilişkin düzenlenen ödeme emrine karşı 2017 yılında açlan davanın istinaf incelemesinde bölge idare mahkemesince 2019 y1lında karar verilmiş olması ve bu yılda yeniden değerleme oranına göre temyiz sınırının 144.000 TL olmasından hareketle temyiz istemini incelenmeksizin reddetmiştir ${ }^{32}$.

Danıştay yukarıda yer verilen kararlarında genellikle gerekçe olarak, İYUK'un 46. maddesinin birinci fikrasının (b) bendi ve bu bentte yer alan parasal miktarın her yıl yeniden değerleme oranına göre artırılmasına ilişkin aynı kanunun ek 1. maddesindeki hükme yer vermekte ve ayrıca bazı kararlarında IYYUK'un 46. maddesinde değişiklik yapan 6545 sayılı Kanun'un genel gerekçesindeki; Danıştay'ın iş yükünün azaltılması ve gerçek anlamda bir içtihat mahkemesine dönüştürülmesi gerektiğine ilişkin açılamalara atıf yapmaktadır ${ }^{33}$. Bir diğer deyişle Danıştay'a göre temyiz sınırında bölge idare mahkemelerinin karar verdiği tarihin esas alınması, IYYUK'un 46. maddesinin birinci fikrasının (b) bendi ve bu bentte yer alan parasal miktarın her yıl yeniden değerleme oranına göre artırılmasına ilişkin aynı kanunun ek 1. maddesinde yer alan hüküm ile 6545 sayılı Kanun'un genel gerekçesinin bir gereği olarak ortaya çıkmaktadır. Ayrıca Danıştay tarafından bu yönde verilen kararlar arasında, daireler arası bir içtihat birliğinden de bahsedilebilir. Zira birbirinden farklı daireler, bu konu hakkında aynı yönde kararlar vermektedirler.

32 Bkz. "Konusu para ile ölçülebilen davalara ilişkin olarak idare mahkemelerince verilen kararlara karşı istinaf kanun yoluna başvurulması üzerine, bölge idare mahkemelerince verilen kararların temyize tabî olup olmadı̆̆ının, istemde bulunulan parasal tutarın bölge idare mahkemelerince karar verildiği tarihteki temyiz sınırını altında olup olmadığına göre belirlenmesi gerekmektedir." D.13.D., 2.10.2019, E. 2019/3365, K. 2019/2915.

33 Danıştay'ın bazı kararlarında bu her iki gerekçeye birlikte yer verilirken diğer bazı kararlarında ise bunlardan sadece ilkine yer verilmektedir. Her iki gerekçeye birlikte dayanılarak verilen bazı kararlar için bkz. D.3.D., 26.11.2019, E. 2019/7006, K. 2019/6587. D.4.D., 4.10.2018, E. 2018/7388, K. 2018/8614. D.7.D., 4.10.2019, E. 2019/3475, K. 2019/5248. Sadece birinci gerekçeye dayanılarak aynı yönde verilen bazı kararlar için bkz. D.14.D., 17.10.208, E. 2018/4601, K. 2018/6204. D.6.D., 19.9.2019, E. 2019/16208, K. 2019/7717. D.9.D., 20.11.2019, E. 2019/6812, K. 2019/6040. D.10.D., 21.10.2019, E. 2019/10499, K. 2019/6955. D.13.D., 2.10.2019, E. 2019/3365, K. 2019/2915. D.8.D., 30.6.2020, E. 2020/3346, K. 2020/2917. D.15.D., 6.12.2017, E. 2017/3440, K. 2017/7231. D.15.D., 3.4.2018, E. 2018/748, K. 2018/3303. D.10.D., 28.5.2020, E. 2020/1370, K. 2020/1413. 
Danıştay'ın burada bahsedilen gerekçelerden hareketle temyiz s1nırında bölge idare mahkemelerince karar verildiği tarihin esas alınması gerektiği sonucuna ulaşması, kanaatimizce isabetli bir yaklaşım olarak değerlendirilemez. Öncelikle belirtmek gerekir ki İYUK'un 46. maddesinde değişiklik yapan 6545 sayılı Kanun'un genel gerekçesi ile madde gerekçelerinde, temyiz sınırının belirlenmesinde bölge idare mahkemelerince karar verildiği tarihin esas alınması gerektiğine ilişkin bir açılamaya yer verilmemiştir. Söz konusu kanunun genel gerekçesinde yer alan, Danıştay'ın iş yükünün hafifletilmesi ve gerçek anlamda bir içtihat mahkemesine dönüştürülmesi amacıyla bu kanunun hazırlandığına yönelik açıklama, anılan kanunla getirilen düzenlemelerin genel amacını oluşturmakta, temyiz sınırının ne şekilde uygulanacağına yönelik bir içerik taşımamaktadır. Bu genel amaçtan hareketle, temyiz sınırı hakkında bölge idare mahkemeleri tarafından verilen kararların karar tarihinin esas alınacağı ve böylece Danıştay'ın iş yükünün hafifletileceği şeklinde bir sonuca ulaşılması mümkün değildir.

Danıştay'ın mezkûr kararlarında esas aldığı diğer gerekçe de verilen kararların haklılığını ortaya koymaya yeterli değildir. Zira İYUK'un 46. maddesinde, konusu 100.000 TL'yi aşan idari davaların Danıştay'da temyiz denetimine tabi tutulacağı öngörülürken, yukarıda belirtildiği üzere 2576 sayılı Kanun ile bir alt başlıkta belirtileceği üzere 6100 sayılı Hukuk Muhakemeleri Kanunu (HMK)'nda yer verilen hükümlerin aksine, bu miktarın bölge idare mahkemelerince karar verildiği tarih esas alınarak belirleneceğine ilişkin açı bir düzenlemeye yer verilmemiştir. Hatta kanaatimizce bunun tam aksine lafzi olarak 46. maddenin birinci fıkrasının (b) bendinde, "Konusu yüz bin Türk Lirasını aşan vergi davaları, tam yargı davaları ve idari işlemler hakkında açılan davalar" hükmüne yer verilirken "açılan davalar"dan bahsedilmiş olması nedeniyle, bu kapsamda yer alan davaların açıldığı tarihe vurgu yapılmış olduğu da söylenebilir ${ }^{34}$. Yani söz konusu hükümden lafzi olarak, temyiz sınırının böl-

$34 \mathrm{Bu}$ düzenlemenin önemine işaret eden bir görüş için bkz. BOZ/TETIK/BÖLÜKBAŞI/NACAK, s. 92-93. Adı geçen yazarlar, ayrıca İYUK'un 46. maddesinin birinci fikrasının ilk cümlesinde bölge idare mahkemeleri tarafından "verilen kararlar"ın temyizinden bahsediliyor olması nedeniyle, bu mahkemelerce karar verilen tarihin de temyize esas alınabileceğini, yani bu hükmün bu şekilde de yorumlanmaya müsait olduğunu belirtmektedirler. Aynı yerde, s. 92-93. Kanaati- 
ge idare mahkemelerince verilen kararların tarihlerine göre değil de idari davaların açılmış olduğu tarihlere göre belirleneceği yönünde bir anlam çıkarmak mümkündür. Danıştay 10. Dairesi'nce verilen bir kararın karşı oy yazısında bu hususa oldukça isabetli bir şekilde işaret edilmiştir. Anılan karşı oy yazısına göre "2577 sayılı Kanun'un yukarıda aktarılan maddelerinde (yukarıda 46/1-b ve ek 1. madde aktarıliyor), konusu belli bir para olan tam yargı davalarında verilen kararlardan hangisinin, 2577 sayıl Kanun'un 46/1-(b) maddesi uyarınca temyize tabi olup olmadı̆̆ının; 'verilen karara göre' değil, açılan davalardaki parasal miktara göre yapılacă̆̆ hükme bağlandı̆̆ından; bu husustaki değgerlendirmenin dava açma tarihinde yürürlükte bulunan temyiz parasal sinırının esas alınarak yapılması gerekmektedir. Aksi uygulamanın, 2577 sayıl Kanun'da belirtilen parasal sintrlar yıl itibariyle yeniden değerleme oranında arttırıldı̆̆̆ndan, davanın açılmasından sonraki yargilama sürecine göre kararn temyiz edilebilme durumunun değişmesi nedeniyle, kanun yollarına başvurma açısından, kanuni açılığın bulunmadı̆̆ı sonucunun (sonucunu olacak) doğuracă̆ı açıktır." 35 Öte yandan IYYUK'un ek 1. maddesinde yer alan, bu kanunda öngörülmüş olan parasal sınırların her yıl yeniden değerleme oranına göre artırılacağına ilişkin hüküm ise her ne kadar lafzen temyiz sınırını da kapsayacak şekilde bu kanunda öngörülen tüm parasal sınırların her yıl artırılması sonucunu doğuracak olsa da, üçüncü bölümde ayrıntılı bir şekilde inceleneceği üzere bu artışların görülmekte olan davalara bir etkisinin olamaması gerekir.

\section{B. Yargıtay İçtihadı}

Temyiz sınırına ilişkin kurallara HMK'da da yer verilmiş ve Yarg1tay içtihatları da buna göre şekillenmiştir. Fakat HMK'da yer alan bu kurallara bakıldığında, bunların IYUK'da yer alanlardan oldukça farklılıklar içerdiği görülmektedir. Söz konusu kanuna göre, miktar veya değeri kırk bin Türk Lirasını (bu tutar dâhil) geçmeyen davalara ilişkin bölge adliye mahkemelerinin kararları hakkında temyiz yoluna başvu-

mizce söz konusu hüküm bu şekilde yorumlanamaz. Bu hükümde, lafzi olarak temyize esas olmak bakımından bölge idare mahkemelerinin karar verdiği tarihin esas alınacağına yönelik bir vurgu bulunmamaktadır. Burada, sadece cümlenin akış1 içerisinde bölge idare mahkemelerinin karar vermesinden bahsedilmiştir.

35 D.10.D., 12.10.2020, E. 2020/4748, K. 2020/3610. Bu kararın künyesine BALCI'nın makalesinden ulaşılmıştır. Bkz. BALCI, s. 8. 
rulamaz (md. 362/1, a). Ayrıca HMK'nın 362. maddesinin ikinci fıkrasına göre, bölge adliye mahkemelerinin bu kararlarında alacağın bir kısmının dava edilmiş olması durumunda söz konusu parasal kesinlik sınırı alacağın tamamına göre belirlenmekte, alacağın tamamının dava edilmiş olması hâlinde ise kararda asıl talebinin kabul edilmeyen bölümü kırk bin Türk Lirasını geçmeyen tarafın temyiz hakkı bulunmamakta, ancak karşı tarafın temyiz yoluna başvurması halinde, diğer tarafın da düzenleyeceği cevap dilekçesiyle kararı temyiz etmesi mümkün bulunmaktadır ${ }^{36}$. Aynı kanunun ek 1. maddesine göre ise bu kanunda öngörülen diğer parasal sınırlarla birlikte temyiz sınırı da her takvim yılı başından geçerli olmak üzere Hazine ve Maliye Bakanlığı'nca belirlenen yeniden değerleme oranına göre artırılmaktadır. Bu çerçevede en son 2021 yılında yayımlanan yeniden değerleme oranına göre kanunda yer alan bu sinır, 78.630 TL olmuştur ${ }^{37}$.

Fakat yine İYUK'tan farklı olarak HMK'nin ek 1. maddesinin ikinci fıkrasında şu şekilde bir hükme daha yer verilmiştir: "200 üncü ve 201 inci maddelerdeki parasal sınırların uygulanmasında hukuki işlemin yapıldığı, 341 inci, 362 nci ve 369 uncu maddelerdeki parasal sinırlarm uygulanmasinda hükmün verildiği tarihteki miktar esas alınır." Bu hükme göre, medeni yargilama usulünde temyiz sınırı HMK'nın 362. maddesinde düzenlendiğinden, bu alanda söz konusu parasal sınırın uygulanmasında bölge adliye mahkemelerince hükmün verildiği tarihteki miktarın esas alınması söz konusu olacaktır. Görüldüğü üzere bu zorunluluk, doğrudan HMK'nın ek 1. maddesinin ikinci fikrasından kaynaklanmaktadır. Yuka-

36 Bu konular hakkında bu şekilde açık düzenlemelere IYYUK'ta yer verilmemiştir. Fakat yukarıda belirtildiği üzere Danıştay içtihatlarıyla idari yargılama usulünde kabul edilmiş olunan parasal sınır uygulamasında -temyiz sınırı da dâhil olmak üzere-, bölge idare mahkemelerince karar verilen miktarların değil davacılar tarafından dava dilekçesinde talep edilen miktarların esas alınması gerektiği kabul edilmiştir. Bununla birlikte doktrinde, $\mathrm{HMK}^{\prime}$ da yer alan düzenlemelere benzer şekilde bir uygulamanın geliştirilmesinin daha doğru olacağını savunan yazarlar da vardır. Bu yöndeki görüşler için bkz. ÇAĞLAYAN, İdarî Yargılama Hukuku, s. 764766. ÇAĞLAYAN, Ramazan, İdarî Yargı Kararlarına Karşı Başvuru Yolları (FransaTürkiye Mukayeseli Bir Deneme), 1. Baskı, Seçkin Kitabevi, Ankara, 2017, s. 312. KAPLAN, Gürsel, İdari Yargılama Hukuku, Ekin Basın Yayın Dağıtım, Bursa, Eylül 2019, s. 542-543.

37 MERİÇ, Nedim, "HMK ve İIK'da Yer Alan Parasal Sınırlar", https://legalbank.net, Erişim Tarihi: 11.2.2021. 
rıda belirtildiği üzere idari yargılama usulünde buna benzer bir düzenlemeye, tek hâkimle karar verilmesinde parasal sınırı düzenleyen 2576 sayılı Kanun'da da yer verilmiş; fakat bu yönde açık bir düzenlemeye, istinaf ve temyiz sınırı hakkında yer verilmemiştir. Bu nedenle ilke bazında, konuya ilişkin gelişen Yargıtay içtihatları da isabetli bir şekilde Danıştay içtihatlarından farklılık göstermektedir.

Bu çerçevede Yargitay, HMK'da yer alan söz konusu düzenlemelere uygun olarak temyiz başvurularında, bölge adliye mahkemelerince karar verilen tarih ve değeri esas alarak bir temyiz sınırı değerlendirmesi yapmakta ve buna göre karar vermektedir ${ }^{38}$.

\section{Anayasa Mahkemesi'nin İçtihadı}

Temyiz sınırında yapılan artışlardan dolayı açmış oldukları davaların temyiz yolu Yargıtay ve Danıştay tarafından kapatılan kişiler, mahkemelerce verilen bu kararların adil yargılanma haklarını ihlal ettiği ve eşitlik ilkesine aykırılık oluşturduğu gerekçesiyle, bireysel başvuru yoluyla Anayasa Mahkemesi'ne başvurmaktadırlar. Anayasa Mahkemesi bu çerçevede yapılan başvuruları, adil yargılanma hakkının bir unsuru olarak değerlendirdiği mahkemeye erişim hakkı kapsamında ele almakta, fakat bu başvurulara konu mahkeme kararlarının söz konusu hakkı ihlal etmediği yönünde kararlar vermektedir.

Anayasa Mahkemesi'nin bu konuda medeni ve idari yargilama usulüne ilişkin yaklaşımında da bir farklılık yoktur. Karar düzeltme talebi, kanunda öngörülen sınırın altında kaldığı gerekçesiyle Yarg1tay'ca reddedilen kişinin yapmış olduğu başvuruda Anayasa Mahkemesi; temyiz kanun yolunu da aynı çerçeve içerisinde değerlendirerek Yargıtay'ın bu konuya ilişkin yukarıda belirtilen yerleşik içtihadına atıf yaparak kişinin karar düzeltme talebinin reddedilmesinin açı bir takdir

38 Y.10.HD., 15.12.2020, E. 2020/6944, K. 2020/7214. Y.10.HD., 15.12.2020, E. 2020/6955, K. 2020/7216. Y.10.HD., 15.12.2020, E. 2020/6970, K. 2020/7207. Y.10.HD., 16.12.2020, E. 2020/8477, K. 2020/7307. Y.1.HD., 17.12.2020, E. 2019/4182, K. 2020/6821. Y.1.HD., 17.12.2020, E. 2019/3348, K. 2020/6822. Y.15.HD., 19.11.2020, E. 2020/222, K. 2020/3041. Y.15.HD., 23.11.2020, E. 2020/1762, K. 2020/3060. YHGK., 23.11.2011, E. 2011/10-643, K. 2011/707. 
hatası ya da keyfilikten kaynaklanmadığına, bu nedenle söz konusu Yargıtay kararının hukuka uygun olduğuna karar vermiştir ${ }^{39}$.

Anayasa Mahkemesi'nin bu kararı, temyiz sınırındaki artışların görülmekte olan davaları da etkileyeceğine ilişkin HMK hükümleri karşısında oldukça isabetlidir. Zira yasa koyucu HMK'da bu husus hakkında açı bir düzenlemeye yer vermiştir ve kanunda bu şekilde açıkça yer verilen bir düzenlemeye rağmen, Anayasa Mahkemesi'nin bireysel başvurularda farklı yönde bir karar vermesi mümkün değildir. HMK'da bu şekilde yer verilen hükümlerin hukuk devleti ve eşitlik ilkesine uygun olup olmadığı ise bundan farklı bir konudur. Bu hükümlerin söz konusu anayasal ilkelere aykırılık oluşturduğu iddiasıyla ancak Anayasa Mahkemesi'ne, norm denetimine ilişkin bir başvuru yapılabilir. Bu nitelikteki başvurular, bireysel başvuru yolunun konusunu ise oluşturamaz. Kanaatimizce temyiz sınırındaki artışların görülmekte olan adli davaları da etkileyeceğine ilişkin HMK hükümleri, üçüncü bölümde belirteceğimiz gerekçelerle hukuk devleti ve eşitlik ilkesine aykırılık oluşturmaktadır.

Öte yandan idari yargılama usulüne ilişkin olarak ise Anayasa Mahkemesi bir kararında, vermiş olduğu karar bir başka hususa ilişkin olmakla birlikte, temyiz sınırındaki artışların görülmekte olan idari davalarda da uygulanması gerektiğini IYYUK'un 46. maddesinin birinci fıkrasının (b) bendi ile ek 1. maddesinin bir gereği olarak görmüş ve temyiz sınırının bölge idare mahkemesince karar verildiği tarihe göre belirleneceğini belirtmiştir ${ }^{40}$.

Anayasa Mahkemesi'nin bu kararı ise eleştiriye oldukça açıktır. Zira Anayasa Mahkemesi bu kararında, her ne kadar idari yargılama usulündeki temyiz sınırının artırılmasının görülmekte olan davaları da etkileyeceğine ilişkin bir yasal dayanak göstermiş de olsa -İYUK'un 46. maddesinin birinci fikrasının (b) bendi ile ek 1. maddesi-, dikkat edilirse IYYUK'ta yer alan söz konusu hükümlerde, HMK'daki düzenleme yaklaşımından farklı olarak açıkça temyiz sınırının artırılmasının görülmekte olan davaları da etkileyeceğine ilişkin açı bir düzenlemeye yer veril-

\footnotetext{
39 AYM, S. D. Başvurusu, B. No. 2013/8884, 13.4.2016, \& 15-16, 33.

40 AYM, Marka Madeni Yağ Sanayi Ticaret Ltd. Şti. Başvurusu, B. No. 2018/20215, 20.10.2020, \& 32, 33.
} 
memiştir. Anayasa Mahkemesi, idari yargılama usulüne özgü bu ayrıntıyı mezkûr kararında gözden kaçırmıştır. Kanaatimizce bu ayrıntıdan hareketle Anayasa Mahkemesi'nin, bir alt başlıkta ortaya koymaya çalışacağımız anayasal ilkelere dayanarak, idari yargılama usulünde temyiz sınırındaki artışların görülmekte olan davaları etkilemeyeceği yönünde bir içtihat geliştirmesinin önünde hiçbir hukuki engel bulunmamaktadır.

\section{DANIŞTAY İÇTİHADININ DEĞERLENDİRILMESI}

İdari yargılama usulünde temyiz sınırının her yıl artırılmasının görülmekte olan idari davalara etkisi hakkında yukarıda ortaya koymaya çalıştığımız Danıştay içtihadı, hukuk devleti ve eşitlik ilkesi açısından ciddi sorunları bünyesinde barındırmaktadır.

Şöyle ki hukuk devleti ilkesi, birçok gerekliliği bünyesinde barındırmakla birlikte öz bir ifadeyle temel hak ve özgürlüklerin anayasal düzeyde güvence altına alındığı, devletin her türlü faaliyetinin buna göre hukuk kuralları ile düzenlendiği ve devletin de buna uymasını sağlamaya yönelik güvencelerin getirildiği bir devlet sistemini ifade eder. Bu gereklilikler içerisinde hukuk devleti; kişilere, toplum içerisinde ve özellikle devlet karşısında hukuki güvenlik sağlar ve herkesin kurallara uymasını zorunlu kılarak adil bir devlet yönetimini garanti eder. Bu açıdan hukuk devleti ilkesinin en önemli unsurlarından birini hukuki güvenlik ilkesi oluşturur. Bu ilke ise devlet tarafından yürürlüğe konulan hukuk kuralları ile uygulamanın ve hatta mahkeme içtihatlarının düzenli, belirli, öngörülebilir ve istikrarlı olmasını gerektirir. Belirli bir düzeyde açıklık oluşturmayan ve geleceğe yönelik uygulaması hakkında bir öngörülebilirlik ortaya koymayan hukuk kurallarının ve mahkeme içtihatlarının, kişilerin hukuki bir güven içerisinde yaşamalarını sağlaması mümkün değildir. Yukarıda yer verilen Danıştay içtihadına bu açıdan yaklaşıldığında, bu içtihadın kişilere hukuki güvenlik sağlamadığı rahatlıkla söylenebilir. Zira bu içtihadı ile Danıştay, konusu para olan idari davalar açılırken aslında davanın açıldığı tarihte yürürlükte olan kurallara göre ileride temyize tabi tutulması mümkün olan davaları, öngörülemez bir şekilde her yıl yürürlüğe konulan yeniden değerleme oranlarına göre temyize tabi olmaktan çıkarmaktadır. Elbette bir idari dava açıldıktan sonra yargılama usulüne ilişkin kurallarda değişiklikler yapılabilir ve derhal uygulama ilkesinin gereği olarak bu kuralların görülmekte olan 
davalar hakkında da uygulanması söz konusu olabilir. Fakat idari yargılama usulündeki parasal sınırların her yıl yeniden değerleme oranına göre artırılmasının görülmekte olan idari davaları da etkileyeceğinin kabul edilmesi halinde, kişiler açısından öngörülebilir bir dava sürecinin gerçekleştirilmesi söz konusu olamamakta ve hukuk kurallarının belirliliği ciddi mahiyette aşınmaktadır. Bu uygulama yüzünden kişiler davalarını açarken, açmış oldukları bu dava hakkında verilen ilk derece mahkemesi kararına karşı ileride temyiz hakkına sahip olup olamayacakların bilememekte ve dava tarihindeki hukuk düzeninin güvencelerine güvenememektedirler. Hatta belki de kişilerin, ileride temyiz denetimine tabi tutulması mümkün bir dava olduğu düşüncesiyle dava açmaya karar vermeleri durumu dahi söz konusu olabileceğinden, bu uygulama dava açma hakkını da olumsuz etkilemektedir ${ }^{41}$.

Öte yandan hukuk devleti ilkesinin gereklerinden bir diğeri ise adil yargılanma hakkının güvence altına alınmış olmasıdır. Anayasa'nın 36. maddesinde, herkesin meşru vasıta ve yollardan faydalanmak suretiyle yargı mercileri önünde davacı veya davalı olarak iddia ve savunma ile adil yargılanma hakkına sahip olduğu belirtilmiş; ayrıca bu hakka, tarafı olduğumuz AİHS'nin 6. maddesinde de yer verilmiştir. Adil yargılanma hakkı, kaideten usule ilişkin bir hak olarak bağımsız ve tarafsız mahkemelerce yapılan yargılamanın adil bir şekilde yürütülmesini konu alır. Yargılama sonunda verilen hükmün adil olup olmaması, kural olarak adil yargılanma hakkı ile ilgili bir konu değildir ${ }^{42}$. Adil yargılanma hakkı doktrinde ve mahkeme içtihatlarında bazı unsurlara ayrılarak incelenmekte, bu çerçevede makul sürede yargılanma hakkı, mahkemeye erişim hakkı, hükmün denetlenmesini talep etme hakkı, gerekçeli karar hakkı ve hakkaniyete uygun yargılanma hakkı gibi bazı haklar bu

41 Aynı görüşte bkz. BOZ/TETİK/BÖLÜKBAŞI/NACAK, s. 93-94. Temyiz sınırında yeniden değerleme oranına göre artış yapılacağına ilişkin Hukuk Muhakemeleri Kanunu'nda yer alan hükümlerin de burada belirttiğimiz aynı gerekçelerle hukuki güvenlik ilkesine aykırılık oluşturduğu hakkında bkz. PEKCANITEZ, Yargıtay Yönünden, s. 418. PEKCANITEZ, Hukuk Muhakemeleri, s. 213-214. TAŞPINAR AYVAZ, s. 164-165.

42 AYM, Barış Erdem Gürbüz Başvurusu, B. No. 2016/2270, 26.2.2020, \& 27, 33. AYM, Abdurrahman Şanda Başvurusu, B. No. 2014/3907, 7.12.2016, \& 36. 
hak kapsamında değerlendirilmektedir ${ }^{43}$. Temyiz sınırı uygulaması ise mahkemeye erişim hakkı ve hükmün denetlenmesini talep etme hakkıyla ilgili bir konu olarak ele alınmaktadır ${ }^{44}$.

Mahkemeye erişim hakkı, demokratik bir toplumda kabulü mümkün olmayan bir engelle karşılaşmaksızın kişilerin dava açabilmelerini ve açtıkları davaların bağımsız ve tarafsız mahkemelerce etkin bir şekilde sonuçlandırılmasını ifade eder ${ }^{45}$. Bu hak, sadece ilk derecede dava açılmasını değil bununla birlikte kanun yolları aşamasını da güvence altına alır. Bu nedenle mahkemeye erişim hakkının getirmiş olduğu güvencelerden kişilerin; istinaf, temyiz ve yargılamanın yenilenmesi gibi kanun yolu başvurularında da yararlandırılması gerekir ${ }^{46}$. Anayasa Mahkemesi ve Danıştay içtihatları da bu yöndedir ${ }^{47}$.

Hükmün denetlenmesini talep etme hakkı ise mahkemeye erişim hakkının özel bir görünümü olarak ilk derece mahkemelerince verilmiş olan hükümlerin, üst derece mahkemelerince denetlenmesini talep etmeyi konu alır. Mahkeme kararlarının hatalı olabilme ihtimali, nihai mahkeme kararlarının daha tecrübeli hâkimlerin denetiminden geçirilmesine duyulan ihtiyaç, mahkeme kararlarına karşı adalet duygusunu

43 AYDIN, Bihter, "Türk İdari Yarg1 Düzeninde Mahkemeye Erişim Hakkı”, Türkiye Adalet Akademisi Dergisi, Y1l. 4, Sayı. 15, Ekim 2013, s. 274. EKİNCI, Ahmet, "Anayasa Mahkemesi'nin Bireysel Başvuru Kararlarında Mahkemeye Erişim Hakkı", Gazi Üniversitesi Hukuk Fakültesi Dergisi, C. XVIII, Sa. 3-4, 2014, s. 825. ÇİFTÇİ, Erhan, “Avrupa İnsan Hakları Mahkemesi Kararları Işığı Altında Adil Yargılama İlkesi ve İdari Yarg1", Danıştay Dergisi, Yı1. 33, Sayı. 106, 2003, s. 86 vd.

44 AYM, Marka Madeni Yağ Sanayi Ticaret Ltd. Şti. Başvurusu, B. No. 2018/20215, 20.10.2020, \& 26. AYM, Emine Halaç ve Diğerleri Başvurusu, B. No. 2017/38981, 15.9.2020, \& 30. AYM, E. 2020/21, K. 2020/53, 1.10.2020, \& 26.

45 AYDIN, s. 272. ÇAYAN, Gökhan, “Avrupa İnsan Hakları Mahkemesi ve Anayasa Mahkemesi Kararları Işığında Mahkemeye Erişim Hakkı", Türkiye Adalet Akademisi Dergisi, Y11 7, Sayı 28, Ekim 2016, s. 238. Aynı yönde bkz. AYM, Marka Madeni Yağ Sanayi Ticaret Ltd. Şti. Başvurusu, B. No. 2018/20215, 20.10.2020, \& 24. AYM, Aladdin Özdemir Başvurusu, B. No. 2018/36426, 21.10.2020, \& 24. DİDDK, 27.11.2019, E. 2019/975, K. 2019/6006. AYM, Abdurrahman Şanda Başvurusu, B. No. 2014/3907, 7.12.2016, \& 26.

46 YILMAZ, (Ejder), s. 142. AYDINOĞLU, s. 393. ÇAYAN, s. 240. SANCAKDAR, s. 41.

47 AYM, Marka Madeni Yağ Sanayi Ticaret Ltd. Şti. Başvurusu, B. No. 2018/20215, 20.10.2020, \& 25, 26. AYM, Abdurrahman Şanda Başvurusu, B. No. 2014/3907, 7.12.2016, \& 27. AYM, Ayhan Şaşar Başvurusu, B. No. 2016/15514, 23.10. 2019, \& 19. D4D, 6.10.2020, E. 2020/2183, K. 2020/3476. 
bu kararları bir kez daha denetimden geçirerek tesis etme düşüncesi ve içtihatların birleştirilmesinde yüksek mahkemelerin oynayacağı önemli rol gözetilerek, AİHM ve Anayasa Mahkemesi içtihatlarında hükmün denetlenmesini talep etmek ayrı bir hak olarak gelişim göstermiştir ${ }^{48}$.

$\mathrm{Bu}$ çerçevede temyiz sınırındaki artışların görülmekte olan davaları etkilemesine yönelik bir uygulamanın, mahkemeye erişim hakkı ile hükmün denetlenmesini talep etme hakkını da ihlal ettiği kanaatindeyiz. Elbette temyize parasal sınır getirilmesi ve bu sınırın enflasyon karşısında her yıl artırılacağına ilişkin bir yasal düzenleme yapılması, doğrudan söz konusu hakların ihlali sonucunu doğurmaz. Bu tür düzenlemeler ancak demokratik toplum düzeninin gereklerine uygun olmadığı, söz konusu hakların özüne dokunduğu ya da bu hakları ölçüsüz bir biçimde sınırlandırdığı durumlarda bir hak ihlali gerçekleşmiş olur. Kanaatimizce işte burada temyiz sınırı artışlarının görülmekte olan davaları da etkilemesine yönelik bir uygulamanın, hukuki belirliliği ve öngörülebilirliği ortadan kaldırıyor olması nedeniyle birlikte mahkemeye erişim hakkı ile hükmün denetlenmesini talep etme hakkının kullanılmasını, bu hakların özüne dokunacak ve demokratik toplum düzeninin gereklerine uygun olmayacak şekilde sinırlandırdığı söylenebilir. Anayasa Mahkemesi, mahkemeye erişim hakkı ile ilgili vermiş olduğu bazı kararlarında konuya ilişkin AİHM kararlarını da esas alarak şu şekilde bir değerlendirme yapmaktadır: "Mahkemeye etkili erişim hakkl; mahkemeye başvuru konusunda tutarlı bir sistemin var olmasını, dava açmak veya kanun yoluna başvurmak isteyen kişilerin ilgili mahkemeye ulaşmada açık, pratik ve etkili firsatlara sahip olmasın gerektirmektedir. Özellikle hukuki belirsizlikler ya da uygulamadaki belirsizlikler kişilerin mahkemeye erişim hakkını ihlal edebilmektedir." ${ }^{49}$ Bu değerlendirmeyi esas aldığımızda aslında Anayasa Mahkemesi'nin, idari yargılama usulünde temyiz sınırındaki artışların görülmekte

48 Fakat Anayasa Mahkemesi'nin; idari davalardan medeni hak ve yükümlülüklerle ilgili olmayanların, hükmün denetlenmesini talep etme hakkı kapsamında güvence göremeyeceğine ilişkin bireysel başvuru üzerine verilmiş birçok kararının bulunduğunu da ayrıca belirtmek gerekir. Bu yönde verilmiş bazı kararlar için bkz. AYM, İhsan Murat Düz Başvurusu, Başvuru No. 2018/26178, 14.10.2020, \& 19-21. AYM, Cemal Emre Gürsoy Başvurusu, Başvuru No. 2016/7760, 3.6.2020, \& 23 vd. AYM, Engin Çolak Başvurusu, Başvuru No. 2019/2490, 3.12.2020, \& 38-40. 
olan idari davaları etkilememesi gerektiği hakkında bizim burada ifade etmeye çalıştığımız görüş doğrultusunda bir içtihadı da ortaya koyması gerekirdi. Fakat yukarıda belirtildiği üzere Anayasa Mahkemesi, konu hakkında aksi yönde bir içtihat geliştirmiştir.

Nihayet hukuk devleti ilkesi çerçevesinde bu uygulama, tabii hâkim ilkesini de ihlal eder ${ }^{50}$. Zira bu ilkeye göre bir hukuki uyuşmazlı̆̆ın hangi mahkemede ve ne şekilde görüleceği, henüz söz konusu hukuki uyuşmazlık ortaya çıkmadan önce kanunen belli olmalıdır ${ }^{51}$. Temyiz sınırının artırılmasının görülmekte olan davaları etkileyeceğinin kabul edilmesi halinde kişiler, dava açarken açmış oldukları davanın temyize tabi olup olamayacağını kesin olarak bilememektedirler.

Burada ortaya koymaya çalıştığımız ilke ve kuralların önemi çok nadiren de olsa bazı Danıştay kararlarında karşı oy olarak kendine yer bulabilmektedir. Örneğin bir Danıştay kararında kullanılan karşı oy gerekçesine göre, “Uyuşmazlık konusu olayda olduğu gibi değeri parayla ölçülen davaların temyiz sınırı Dairemiz çoğunluğuna göre Bölge İdare Mahkemesinin karar tarihine göre belirlenmekte iken, kanaatimizce davacmın davasını açtı̆̆ı tarihe göre temyiz sınırnın tespit edilmesi gerekmekte olup, aksi durumun hukuki belirlilik, hukuki öngörülebilirlik, hak arama hürriyeti ve tabii hakim ilkelerine aykırı olacă̆ı açıktır." 52

Eşitlik ilkesi açısından konuyu ele aldığımız zaman ise davanın ilk derece mahkemeleri ile bölge idare mahkemelerince karara bağlanma süresine göre, kişiler açısından davalarının temyize tabi olması ya da olmaması gibi farklı sonuçlar ortaya çıkmaktadır ${ }^{53}$. Örneğin (A) ve (B)'nin birbirinden ayrı olarak 2018 yılında 170.000 TL maddi ve manevi tazminat istemli birer tam yargı davası açmış olduklarını düşünelim. Davanın açılmış olduğu bu yıl içerisinde temyiz sınırı 117.000 TL olduğundan, bu tarih itibarıyla her iki davanın da temyize tabi tutulması

$50 \quad$ BALCI, s. 3.

51 AYM, E. 2017/32, K. 2018/81, 11.7.2018, \& 45. AYM, E. 2014/92, K. 2016/6, 28.1.2016, \& 58. AYM, Barış Erdem Gürbüz Başvurusu, B. No. 2016/2270, 26.2.2020, \& 49-50.

52 D8D, 30.6.2020, E. 2020/3346, K. 2020/2917. Danıştay 10. Dairesi kararlarında da benzer yönde karşı oy yazılarına yer verildiği bilgisi için bkz. BOZ/TETİK/BÖLÜKBAŞI/NACAK, s. 94, dipnot no. 53.

53 BOZ/TETIK/BÖLÜKBAŞI/NACAK, s. 93. 
mümkünken (A)'nın açmış olduğu davanın 2019 yılında, (B)'nin açmış olduğu davanın ise 2021 yılında bölge idare mahkemesi kararlarıyla sonuçlandığını varsaydığımızda; (A)'nın bu kararı temyiz etmesi mümkün olabilecekken (B)'nin temyiz etmesi ise mümkün olamayacaktır. Çünkü 2019 yılında temyiz sınırı 144.000 TL'dir ve (A)'nın davası hakkında bölge idare mahkemesi bu yıl içerisinde nihai kararını verdiği için bu karar temyize tabidir. 2021 y1lındaki parasal sınır ise 192.000 TL'dir ve (B)'nin davası hakkında bölge idare mahkemesi nihai kararını bu yıl içerisinde verdiği için bu karar temyize tabi değildir. Görüldüğü üzere 2018 yılında açıldıkları tarih itibarıyla her ikisi de ileride temyize tabi tutulabilecek davaların ilk derece mahkemeleri ile bölge idare mahkemelerinde görülme sürelerine göre, bu davaların temyize tabi olması ya da olmaması gibi bir durum ortaya çıkmaktadır. Bu ayrımı haklı kılabilecek hiçbir neden yoktur ${ }^{54}$. Bu uygulama, aynı hukuki statü içerisinde bulunan kişilere mahkemelerin hiçbir haklı nedene dayanmaksızın farklı işlemler tesis etmelerine neden olmakta ve bu nedenle eşitlik ilkesini ihlal etmektedir. Kişiler nazarından konuyu ele aldığımızda ise kendi davasıyla aynı yıl ve aynı hukuki koşullar içerisinde açılan bir davanın temyize tabi tutulabildiğini ve fakat kendi davasının temyize kapatıldığını gören kişinin, adalete ve mahkemelere olan güveninde de ciddi bir sarsıntının söz konusu olacağı söylenebilir.

Öte yandan idari yargılama usulünde görev kurallarının kamu düzeninden kabul edilmesinin bir sonucu olarak bu kurallar kazanılmış hak oluşturmamaktadır ${ }^{55}$. Bu nedenle görev kurallarında meydana gelen değişiklikler, görülmekte olan davaları da doğrudan etkilemekte ve bu davalar yeni görev kurallarına tabi olarak çözümlenmektedir. Bu durum karşısında, yukarıda belirtildiği üzere temyiz sınırı aynı zamanda mahkemelerin görevi ile ilgili bir konu olduğundan, bütün bu anlatılanlara rağmen bu sınıra ilişkin her yıl parasal sınırlarda yapılan artışların görülmekte olan davaları da etkileyeceği ve bir kazanılmış hak durumundan söz edilemeyeceği ileri sürülebilir mi? Aynı soru, yargılama hukukunda geçerlilik bulan derhal uygulama ilkesi kapsamında bir değerlen-

54 BOZ/TETIK/BÖLÜKBAŞI/NACAK, s. 93.

55 AKYILMAZ, Bahtiyar/SEZGINER, Murat/KAYA, Cemil, Türk İdari Yargilama Hukuku, 4. Baskı, Savaş Yayınevi, Eylül 2020, s. 132. 
dirme yapmayı da zorunlu kılmaktadır ${ }^{56}$. Zira bu ilkeye göre yargılama usulüne ilişkin kurallar, yürürlüğe girdikleri andan itibaren görülmekte olan davalar da dâhil olmak üzere onlar üzerinde uygulanma kabiliyeti kazanırlar $^{57}$. Bir yargılama usul kuralı olarak temyiz sınırı da her yıl kanun hükmü gereğince artırıldığından, bunların da derhal uygulama ilkesi gereğince görülmekte olan davalarda uygulanması gerekecek midir?

Kanaatimizce istinaf ve temyiz sınırının görülmekte olan davalara etkisi bakımından karşı karşıya gelen hukuki güvenlik ilkesiyle görev kurallarının kamu düzeninden kabul edilmesi ve derhal uygulama ilkesi arasındaki denge, ancak hukuki güvenlik ilkesine üstünlük tanınarak çözümlenebilir. Zira diğer iki ilkenin var oluş amacı, yeni usul kurallarının kişiler bakımından daha fazla güvence sağlayıcı nitelikte olduklarına ilişkin bir varsayıma dayanır ${ }^{58}$. İstinaf ve temyiz sınırındaki artışların görülmekte olan davaları da etkilemesinin kabul edilmesi halinde ise bunun tam aksine kişiler bakımından daha güvencesiz bir hukuki ortam ortaya çıkacaktır. Bu nedenle istinaf ve temyiz sınırındaki artışlar görülmekte olan davaları etkileyememelidir ${ }^{59}$.

56 Bu ilke, yargılama usul kurallarının yürürlük kazandıkları tarihten itibaren tamamlanmamış usul işlemlerini kapsayacak şekilde görülmekte olan davalarda da, lehe ya da aleyhe olması fark etmeksizin uygulanmasını ifade eder. Bu ilke hakkında bkz. ARSLAN, Ramazan/YILMAZ, Ejder/TAŞPINAR AYVAZ, Sema/HANAĞASI, Emel, Medenî Usul Hukuku, 6. Baskı, Yetkin Yayınları, Ankara, 2020, s. 63-65. HAFIZOĞULLARI, Zeki/AYGÜN EŞITLİ, Ezgi/KÜÇÜKTAŞDEMİ, Özgür, “Avrupa İnsan Hakları Sözleşmesi Bağlamında Ceza ve Ceza Muhakemesi Kanunlarının Zaman Yönünden Sınırı", Başkent Üniversitesi Hukuk Fakültesi Dergisi, C. 1, S. 1, 2015, S. 510-511, http://hukuk2.baskent.edu.tr/dergi/arsiv/sayi1/1.zekihaf\%C4\%B1zo\%C4\%9Fullar\%C4\%B1.pdf, Erişim Tarihi: 1.6.2021. YILMAZ, Halil, "Kanunların Zaman Bakımından Uygulanması (6100 Sayılı Hukuk Muhakemeleri Kanunu Açısından)", Terazi Hukuk Dergisi, Yıl. 6, Sayı. 58, Haziran 2011, s. 64-65.

57 ARSLAN/YILMAZ/TAŞPINAR AYVAZ/HANAĞASI, s. 63-65.

58 ARSLAN/YILMAZ/TAŞPINAR AYVAZ/HANAĞASI, s. 63. HAFIZOĞULLARI/AYGÜN EŞITTLI/KÜÇÜKTAŞDEMİR, s. 511.

59 Doğrudan bu konuyla ilgili olmamakla birlikte, ceza muhakemesi hukuku kurallarının doğrudan uygulanması ilkesinin yorumlanmasında bizimle benzer nitelikte ileri sürülen bir görüş için bkz. HAFIZOĞULLARI/AYGÜN EŞITLI/KÜÇÜKTAŞDEMIR, s. 513-514. Hukuk muhakemesi kurallarının doğrudan uygulanması bakımından yine benzer yönde bkz. YILMAZ, (Halil), s. 65. 
Sonuç olarak yukarıda belirtildiği üzere temyiz sınırının görülmekte olan idari davaları da etkilemesine ilişkin açı bir düzenlemeye IYYUK'ta yer verilmemiştir. Kanaatimizce böylesine açı bir düzenlemeye IYYUK'ta yer verilmemiş olmasını da gözeterek hukuk devleti ilkesinin birer unsuru olan hukuki güvenlik ilkesi, adil yargılanma hakkı ve tabii hâkim ilkesi ile eşitlik ilkesi gereğince temyiz sınırındaki artışların görülmekte olan idari davaları etkileyememesi gerekir.

\section{SONUÇ}

Konusu para olan idari davalarda uygulanmakta olan temyiz sınırının, bölge idare mahkemelerince karar verildiği tarihte geçerli olan temyiz sınırına göre belirleneceğine ilişkin açık bir düzenlemeye IYYUK'ta ve diğer kanunlarda yer verilmemiştir. Tam aksine IYYUK'un 46. maddesinin birinci fikrasının (b) bendinde "Konusu yüz bin Türk lirasinı aşan vergi davaları, tam yargı davaları ve idari işlemler hakkında açılan davalar"ın temyize tabi olacağı belirtilirken davaların açıldığı tarihe vurgu yapıldığından, temyiz sınırı hakkında bölge idare mahkemesi kararının değil davanın açıldığı tarihin esas alınması gerekir. Bu noktada, hukuk yargılamasının aksi yöndeki gelişimine ilişkin Yargıtay içtihatları da idari yargılamaya esas alınamaz. Zira hukuk yargılamasında, temyiz sınırında yeniden değerleme oranında gerçekleşen artışların görülmekte olan davaları etkileyeceğine ilişkin açık bir hükme, HMK'nın ek 1. maddesinde yer verilmiştir.

IYYUK'un bu şekilde yorumlanabilecek 46. madde düzenlemesinin ötesinde, temyiz sınırındaki artışların görülmekte olan idari davaları etkilememesi gerektiği düşüncesi, hukuk devleti ile eşitlik ilkelerinin bir gereği olarak da karşımıza çıkmaktadır. Zira hukuk devleti ilkesi, hukuki belirlilik ve öngörülebilirlik ile adil bir yargılamanın gerçekleştirilmesini zorunlu kıldığ gibi, tabii hâkim ilkesinin gözetilmesini de zorunlu kılar. İdari davaların açıldığı tarih itibarıyla temyize tabi tutulabilecekleri mümkün iken sonradan yeniden değerleme oranları esas alınarak gerçekleştirilen temyiz sınırındaki artışlar ile bu davaların temyize tabi olmaktan çıkarılması, bu ilkelerin açık bir şekilde ihlali sonucunu doğurur. Benzer şekilde bu yöndeki bir uygulama, aynı sebep ve konuyu içermesine rağmen kişilerin açmış oldukları farklı davaların, sırf ilk derece mahkemeleri ile bölge idare mahkemelerinin yapmış olduğu yargı- 
lamanın uzunluğuna göre temyize tabi olması ya da olmaması gibi bir sonuç ortaya çıkarır. Böyle bir sonuç ise kanun önünde eşitlik ilkesini ihlal eder.

Bu nedenle konu hakkında Danıştay'ın vermiş olduğu kararların isabetli olmadığı, bir içtihat değişikliğiyle bu sorunun giderilebileceği söylenebilir. Fakat bunu beklemek yerine, bu konuda İYUK'ta açık bir düzenlemeye yer verilerek sorunun daha hızlı bir şekilde giderilmesi de düşünülebilir. Hukuk yargılaması açısından ise HMK'nın ek 1. maddesinde yer verilmiş olunan aksi yöndeki düzenlemelerde bir değişiklik yapılması gerektiği önerilebilir. Ayrıca burada getirilen önerilerin, sadece idari yargılama usulünde geçerli olan temyiz sınırı bakımından değil daha bütüncül bir yaklaşımla bu alanda öngörülen istinaf ve duruşma sınırı gibi diğer parasal sınır uygulamalarında gözetilmesinde de büyük fayda bulunmaktadır. Parasal sınıra dayalı her türlü idari yargılama açısından, davanın açıldığı tarihte geçerli olan sınırlar esas alınmalı, bu sınırlarda sonradan gerçekleştirilen artışlar görülmekte olan idari davaları etkileyememelidir. 


\section{KAYNAKLAR}

AKYILDIZ, Ali, “İstinafa İlksel Bakmak”, Danıştay ve İdari Yargı Günü 147. Yil Sempozyumu, Ankara, Mayıs 2015, s. 11-32.

AKYILMAZ, Bahtiyar/SEZGİNER, Murat/KAYA, Cemil, Türk İdari Yargılama Hukuku, 4. Baskı, Savaş Yayınevi, Eylül 2020.

ALANGOYA, Yavuz, "Kanun Yolunun Anayasal Temeli ve HUMK m. 427 Hükmü ile Kanun Yolu Kapatılmış Olan Kararlara Karşı Kanun Yoluna Müracaat İmkanı", TBB 75. Yaş Günü İçin Prof. Dr. Baki Kuru Armağanı, Türkiye Barolar Birliği Yayınları No: 55, Ankara, 2004, s. 17-48.

ARSLAN, Ramazan/YILMAZ, Ejder/TAŞPINAR AYVAZ, Sema/HANAĞASI, Emel, Medenî Usul Hukuku, 6. Baskı, Yetkin Yayınları, Ankara, 2020.

ASLAN, Zehreddin ve diğerleri, Açıklamalı ve İçtihatlı İdari Yargılama Usulü Kanunu (Vergi Yargılaması Dahil), Ed. ASLAN, Zehreddin, 1. Baskı, Seçkin, Ankara, 2019.

AVCI, Mustafa "İdari Yargıda İstinaf", Türkiye Barolar Birliği Dergisi, (96), 2011, s. 179-204.

AYDIN, Bihter, “Türk İdari Yarg1 Düzeninde Mahkemeye Erişim Hakkı", Türkiye Adalet Akademisi Dergisi, Yıl. 4, Sayı. 15, Ekim 2013, s. 271-296.

AYDINOĞLU, Zeynep Nihal, "İstinaf Kanun Yolunun İdari Yargılama Usulüne Başlıca Etkileri", Türkiye Adalet Akademisi Dergisi, Y1l 9, Sayı 34, Nisan 2018, s. 387-423.

BALCI, Mustafa, “Vergi Yargisında Parasal Tutar Olarak Kesin Kararlar ve Kanuni Hâkim Yönünden Bazı Sakıncalı Durumlar", https://vergialgi.net/vergi-yargisinda-parasal-tutar-olarakkesin-kararlar-ve-kanuni-hakim-yonunden-bazi-sakincaliduruml, s. 1-13, Erişim Tarihi: 9.4.2021.

BOZ, Selman Sacit/TETIK, Ahmet Talha/BÖLÜKBAŞI, Mustafa Oğuzhan/NACAK, Mehmet, Türk İdari Yargılama Hukukunda Temyiz, 1. Baskı, Ed. BOZ, Selman Sacit, Adalet Yayınevi, Ankara, 2021. 
ÇAĞLAYAN, Ramazan, İdarî Yargılama Hukuku, 12. Baskı, Seçkin Kitabevi, Ankara, 2020.

ÇAĞLAYAN, Ramazan, İdarî Yargı Kararlarına Karşı Başvuru Yolları (Fransa-Türkiye Mukayeseli Bir Deneme), 1. Baskı, Seçkin Kitabevi, Ankara, 2017.

CANDAN, Turgut, Açıklamalı İdari Yargılama Usulü Kanunu, 8. Baskı, Yetkin Yayınları, Ankara, 2020.

ÇAYAN, Gökhan, “Avrupa İnsan Hakları Mahkemesi ve Anayasa Mahkemesi Kararları Işı̆̆ında Mahkemeye Erişim Hakkı", Türkiye Adalet Akademisi Dergisi, Y1l 7, Sayı 28, Ekim 2016, s. 235-271.

ÇİFTÇİ, Erhan, “Avrupa İnsan Hakları Mahkemesi Kararları Işı̆̆ı Altında Adil Yargılama İlkesi ve İdari Yargı", Danıştay Dergisi, Yıl. 33, Say1. 106, 2003, s. 77-97.

DEMIRKOL, Selami, “İdari Yargılama Usulü Yenilenirken İstinaf Kanun Yolu Öngörüsü-Danıştay'ın İçtihat Mahkemesi Rolü’nün Güçlendirilmesi", 148. Yıl Danıştay ve İdarî Yargi Günü Sempozyumu, Ankara, Mayıs 2016, s. 115-140.

EKİNCI, Ahmet, “Anayasa Mahkemesi'nin Bireysel Başvuru Kararlarında Mahkemeye Erişim Hakkı", Gazi Üniversitesi Hukuk Fakültesi Dergisi, C. XVIII, Sa. 3-4, 2014, s. 821-848.

HAFIZOĞULLARI, Zeki/AYGÜN EŞİTLİ, Ezgi/KÜÇÜKTAŞDEMİR, Özgür, “Avrupa İnsan Hakları Sözleşmesi Bağlamında Ceza ve Ceza Muhakemesi Kanunlarının Zaman Yönünden Sınırı", Başkent Üniversitesi Hukuk Fakültesi Dergisi, C. 1, S. 1, 2015, s. 505-519, $\quad$ http://hukuk2.baskent.edu.tr/dergi/arsiv/sayi1/1.zekihaf\%C4\%B1zo\%C4\%9Fullar\%C4\%B1.pdf, Erişim Tarihi: 1.6.2021.

KAPLAN, Gürsel, İdari Yargılama Hukuku, Ekin Basın Yayın Dağıtım, Bursa, Eylül 2019.

KONURALP, Orhan Emre, “Hâkimlerin ve Bilirkişilerin Hukukî Sorumluluğuna İlişkin Verilen Mahkeme Kararları İçin Uygulanacak Kanun Yoluna Başvuru Sınırı Üzerine Bir Hukuk Genel Kurulu Kararının Düşündürdükleri”, Hacettepe HFD, 9 (2), 2019, s. 533-552. 
MERIÇ, Nedim, “HMK ve İIKK'da Yer Alan Parasal Sınırlar”, https://legalbank.net, Erişim Tarihi: 11.2.2021.

ÖZBAY, İbrahim, “6100 Sayılı Hukuk Muhakemeleri Kanununa Göre İstinaftan Sonraki Temyiz Sistemimizde Temyiz Edilebilen ve Edilemeyen Kararlar", İÜHFM, C. LXIX, S. 1-2, 2011, s. 411-438.

PEKCANITEZ, Hakan, "Yargıtay Yönünden Hukuk Muhakemeleri Kanunu'nun Değerlendirilmesi", TBB Dergisi, 144, 2019, s. 383419.

PEKCANITEZ, Hakan, “Hukuk Muhakemeleri Kanunu'nun Erozyon Süreci", Türkiye Barolar Birliği Dergisi, 133, 2017, s. 211-260.

PEKCANITEZ, Hakan/ATALAY, Oğuz/ÖZEKES, Muhammet, “Hukuk Muhakemeleri Kanunu'nda Değişiklik Yapılmasına Dair 7251 Sayılı Kanun Hakkında Değerlendirme", Türkiye Barolar Birliği Dergisi, 150, 2020, s. 247-299.

SANCAKDAR, Oğuz, "İdari Yargı İstinaf Sistemindeki Olası Sorunlar ve Çözüm Önerileri”, Danıştay ve İdarî Yargı Günü 148. Yıl Sempozyumu, Ankara, Mayıs 2016, s. 29-113.

SEVİNÇ, Ekin, “İdari Yargılama Hukukunda Kanun Yoluna Başvuru Hakkının Anayasal Güvenceye Sahip Olması Bakımından Ele Alınması", Ankara Hacı Bayram Veli Üniversitesi Hukuk Fakültesi Dergisi, C. XXIV, S. 3, 2020, s. 421-445.

TAŞPINAR AYVAZ, Sema, “İstinaftan Sonraki Temyiz İncelemesi ve Sonuçları", Türkiye Barolar Birliği Medenî Usûl ve İcra-İflâs Hukukçuları Toplantısı VI, Medenî Usûl Hukukunda Kanun Yolları ve Arabuluculuk Kanun Tasarısı, İzmir/Çeşme, 19-20 Ekim 2007, s. 151-207.

TOKLU, Esat, “İdari Yargının İstinaf Deneyimi, Karşılaştığı Sorunlar ve Çözüm Önerileri", Danıştay Başkanlığı 150. Yıl Danıştay ve İdari Yargı Günü Sempozyumu 2018, Danıştay Yayınları No. 99, Ankara, 2018, s. 135-145.

YILDIRIM, Ramazan, “Türkiye'de İstinaf Uygulamasının İdari Yargıya Etkileri", Danıştay ve İdari Yargı Günü 147. Yıl Sempozyumu, Ankara, Mayıs 2015, s. 33-53. 
2168 | Doç. Dr. Yasin SÖYLER / Muhammet YILMAZ

YILMAZ, Ejder, “Hukuk Davalarında Yasayollarına Başvuru Hakkı ve Bu Hakkın Sınırlandırılmasının Yerindeliği Sorunu", Türkiye Barolar Birliği Dergisi, S. 1, 1988, s. 131-155.

YILMAZ, Halil, “Kanunların Zaman Bakımından Uygulanması (6100 Sayılı Hukuk Muhakemeleri Kanunu Açısından)", Terazi Hukuk Dergisi, Yıl. 6, Sayı. 58, Haziran 2011, s. 64-67.

Internet Siteleri

https://www2.tbmm.gov.tr/d24/1/1-0918.pdf, Erişim Tarihi: 7.1.2021.

https://www.turmob.org.tr/arsiv/mbs/pratikBilgiler/vergi_davalarinda_ parasal_sinirlar_2020-C.pdf, Erişim Tarihi: 11.2.2021. 